2009

\title{
Regulating Discourtesy on the Bench: A Study in the Evolution of Judicial Independence
}

Bruce Green

Rebecca Roiphe

New York Law School, rebecca.roiphe@nyls.edu

Follow this and additional works at: https://digitalcommons.nyls.edu/fac_articles_chapters

Part of the Courts Commons, Judges Commons, and the Legal Ethics and Professional Responsibility Commons

\section{Recommended Citation}

New York University Annual Survey of American Law , Vol. 64, Issue 3 (2008-2009), pp. 497-558

This Article is brought to you for free and open access by the Faculty Scholarship at DigitalCommons@NYLS. It has been accepted for inclusion in Articles \& Chapters by an authorized administrator of DigitalCommons@NYLS. 


\title{
REGULATING DISCOURTESY ON THE BENCH: A STUDY IN THE EVOLUTION OF JUDICIAL INDEPENDENCE
}

\author{
BRUCE A. GREEN* AND REBECCA ROIPHE**
}

With few exceptions, our discussions of law posit an "ideal," super-human, passionless, judge. In an occasional aside we admit that a judge may be affected by "weakness" when he allows his feelings to enter into his reasoning. But the manner of referring to these "weaknesses" indicates a belief that they are exceptional and pathological. Now even if the humanness of judges were pathological, it would deserve explicit attention as part of "a liberal understanding or science of the law." But calm observation discloses that such "frailties" are normal, not diseased; recurrent, not exceptional. And a study of law which shoves the consideration of the normal and usual into a footnote and labels it 'unusual and morbid' cannot lead to anything like an adequate understanding of the subject.

- Jerome Frank, Law aNd THE Modern Mind (1951)

A judge shall be patient, dignified and courteous to litigants, jurors, witnesses, lawyers, court staff, court officials, and others with whom the judge deals in an official capacity.

- Model Code of Judicial. Conduct Rule 2.8(b)

* Louis Stein Professor of Law and Director, Louis Stein Center for Law and

Ethics, Fordham University School of Law; J.D., Columbia Law School, 1981; B.A., Princeton University, 1978. The idea for this article and many of the ideas in it originated in the course of our retention as consultants on behalf of a judge who faced discipline for alleged impoliteness in the course of judicial work. The matter on which we worked was resolved without a hearing, finding of wrongdoing, or sanction and is not addressed in this article, and the ideas we express here had no role in the judge's defense or any other practical utility. Nonetheless, we acknowledge that our views on the tension between judicial accountability and independence are influenced by having observed the operation of the judicial disciplinary rules and process from the perspective of a judge for whom we have professional admiration and personal affection.

We would like to thank Molly Buetz, Elizabeth Chambliss, Steve Ellmann, Doni Gewirtzman, James Grimmelmann, Ed Purcell, Tanina Rostain, and the participants of the New York Law School Junior Faculty Workshop for their insights.

** Associate Professor of Law, New York Law School; Ph.D., University of Chicago, 2002; J.D., Harvard Law School, 2000; B.A., Columbia University, 1993. 
We like to believe that judges decide cases based on the law, not on emotions. Thus the image of Justice as a goddess, blindfolded to emphasize the judge's inability to see litigants in light that might evoke irrational sympathy. ${ }^{1}$ Beginning in the late nineteenth century, legal realists such as Jerome Frank exposed the myth of the law devoid of the human element, ${ }^{2}$ but the illusion has persisted. ${ }^{3}$ Ever since the Civil War, an important elite within the bar has emphasized judicial courtesy as a way of preserving this ideal of judging as objective, impersonal, and free from the taint of an individual judge's emotions and intuitions. ${ }^{4}$

This understanding of the courts populated by detached and passive judges has come to seem essential to the independence of the judicial branch of government. ${ }^{5}$ This has particularly been so in periods of our history when any of three conditions are present: first, when the democratic process poses a threat of social chaos; second, when courts are resolving the divisive issues of the day in a manner that seems overtly partisan; and finally, when scandals involving judicial conduct become public. ${ }^{6}$ The history of attitudes and rules concerning judicial demeanor, however, demonstrates that this understanding of independence is not necessary to the legitimacy of the judiciary. ${ }^{7}$ This Article explains the persistence of the myth of the emotionally detached judge and argues that judicial (1982).

1. Judith Resnik, Managerial Judges, 96 Harv. L. REv. 374, 382-83, 446-47

2. Jerome Frank, Law and the Modern Mind (2008). See generally Morton J. Horwitz, The Transformation of American Law, 1870-1960: The Crisis of Legal Orthodoxy 188 (1992); Edward A. Purcell, Jr., The Crisis of Democratic Theory. Scientific Naturalism \& the Problem of Value 74-94 (1973).

3. See Erwin Chemerinsky, Seeing the Emperor's Clothes: Recognizing the Reality of Constitutional Decisionmaking, 86 B.U. L. REv. 1069 (2006); Barry Friedman, The History of the Countermajoritarian Difficulty, Part Four: Law's Politics, 148 U. PA. L. REv. 971, 1057-59 (2000).

4. See infra Part II.

5. See, e.g., Confirmation Hearing on the Nomination of John G. Roberts, Jr. to be Chief Justice of the Uniled States Before the S. Comm. on the Judiciary, 109th Cong. 55 (2005), available at http://www.gpoaccess.gov/congress/senate/judiciary/shl09158/55-56.pdf [hereinafter Confirmation Hearings] (statement of Judge John G. Roberts, Jr.) ("Judges are like umpires. Umpires don't make the rules, they apply them. The role of an umpire and a judge is critical. They make sure everybody plays by the rules, but it is a limited role. Nobody ever went to a ball game to see an umpire.").

6. See infra Part II.C-E.

7. See John A. Ferejohn \& Larry D. Kramer, Independent Judges, Dependent Judiciary: Institutionalizing Judicial Restraint, 77 N.Y.U. L. REv. 962, 963-64 (2002) (arguing that both independence and accountability ought to be seen as means to foster a well-functioning judiciary rather than an end in themselves). 
regulation, insofar as it embodies this myth, runs the risk of undermining the quality of judging, obscuring the transparency of judicial decisions, and deterring the development of diverse judicial styles. ${ }^{8}$ The Article concludes that legislatures, the bench, and the bar ought to revive an older strand of independence, which we will refer to as "personal independence." Personal independence ensures that judges can draw on their personalities, emotions, and intuitions to craft solutions to the cases that come before them. ${ }^{9}$

Judicial independence has meant different things at different times. From the beginning of the twentieth century to the present, the emphasis on judicial courtesy marked a growing concern with courtroom atmospherics and the public image of the judiciary. The bar and the judiciary grew increasingly afraid that if this image were not preserved, the public through the legislature would regulate the judicial branch in such a way as to disturb its independence from the political branches. This concern grew to predominate, and by the 1970s, the bar and the judiciary responded by enforcing judicial branch regulation of individual judges. In doing so, they undermined personal independence (championed by a few prominent lawyers and judges including United States Supreme Court Justices William O. Douglas and Hugo Black) by interfering with individual judges' freedom to draw on their own personalities, experiences, and intuitions to decide cases-an aspect of independence that had been taken for granted in the eighteenth and early nineteenth centuries.

Part I of the Article grounds the discussion by explaining how ideas of judicial independence evolved until the late nineteenth century. In the early years following independence, judicial independence was thought to be secured by salary protection and tenure during good behavior; these constitutional guarantees would ensure branch independence by preventing the judiciary from becoming a tool of the executive, while a degree of financial security would also enable judges to exercise virtue by subordinating their own interests to that of the law or the good of all. ${ }^{10}$ In the antebel-

8. See infra Part III.

9. There is an evolving literature on the importance of emotion to the law and the judicial process. See Richard Posner, Emotion us. Emotionalism in Law, in The Passions of the LAW 309, 321-25 (Susan A. Bandes ed. 1999) (arguing that judges should be in tune with the emotions that lead to the moral code of society and should be empathic not simply with the parties before them but with all those affected by a rule or decision). See generally Terry A. Maroney, Law and Emotions: An Emenging Taxonomy, 30 LAW \& HUM. BEHAV. 119 (2006) (providing an overview of this scholarship).

10. See infra Part I.B. 
lum period, a judge's personal and pragmatic sense of the just result was seen as not only consistent with but also critical to the judicial process. The legitimacy and vitality of the judiciary as an institution owed itself, in part, to the judge's ability to bring his entire experience, understanding, and intuition to bear on the cases before him. But the Civil War undermined the legitimacy of the judicial branch by sweeping courts into the ideological and political divide. To restore a sense of legitimacy to the judiciary, observers began to envision judges as machines calibrated to determine the proper meaning of the law. As the nineteenth century drew to a close, the idiosyncrasies of individual judges-that which made them human-grew to seem anathema to an important elite within the bar.

Part II demonstrates how and why certain elites within the bar enshrined this particular view of judges as detached administrators of the law into written standards of courtroom conduct, some of which we refer to as "courtesy rules." 11 The drafters of the 1924 Canons of Judicial Ethics used judicial courtesy rules as a means of promoting the public perception that, unlike the common man, judges are objective, nonpartisan, and predictable. ${ }^{12}$ They did so in order to counter a growing public dissatisfaction with courts, which some observers believed had devolved into mere partisans in the political battles of the day. ${ }^{13}$ The drafters of the Canons hoped that by reinforcing the image of the judge as impersonal and justice as mechanical, they could deflect that anger away from the judiciary to a better shielded target: the law or the Constitution. ${ }^{14}$

As a new generation of jurists grew to accept that judges do, in fact, draw on their own experience and ideology to decide cases, the definition of independence subtly shifted. Part III argues that the drafters of the 1972 Code of Judicial Conduct used the courtesy rules as part of a concerted effort to transform the judiciary into a bureaucratic institution. By doing so, they hoped to promote uniformity and regularity, which they believed would lend legitimacy to the justice system. Thus, they drafted the ethical standards to be binding, and reinforced the judicial hierarchy by enabling judges, lawyers, and bureaucrats to police the ranks of the judiciary. In this way, they hoped to preserve the independence of the judiciary from the other two branches of government without sacrificing the ap-

11. We use the term "courtesy rules" to denote any written rules, whether enforceable or not, which purport to govern judicial demeanor.

12. See infra Part II.

13. See infra Part II.

14. See infra Part II. 
pearance of a consistent and predictable outcome. In doing so, however, the bar overlooked how this new bureaucratic systemlike the Canons that came before-effaced an older assumption implicit in the concept of independence: that judges can and should draw on their own personal experiences and intuitions to decide cases.

Part IV demonstrates how the enforcement of contemporary rules of judicial courtesy reinforces this particular bureaucratic definition of independence. This Part argues that those rules, in operation, deter judges from developing individual courtroom styles suited to the sorts of cases before them and in accord with their own judicial philosophies.

The Article concludes that the judicial courtesy rules reflect a broader unwillingness to part with a conception of judging based on an antiquated understanding of judicial independence. This notion of judging as the suppression of judicial personality plays on a particular longing for certainty and predictability in the law that grows especially intense as the prevailing social norms seem insecure. Clinging to these antiquated symbols, however, provides an illusory justification for judicial activism, distracts judges from pursuing other sources of legitimacy in light of the practical demands of their dockets, and impedes the proliferation of diverse and distinct judicial styles. Thus, ironically, the antidote designed to relieve courts of public displeasure invites more problems than it solves. To avoid such consequences, judicial courtesy rules should be cautiously enforced.

Scholars are engaged in an extended dialog about the meaning of judicial independence. ${ }^{15}$ This debate, in turn, has enormous implications for the role the judiciary should play in American democracy. ${ }^{16}$ Up until this point, the discussion has ignored the active role the bench and bar have played in perpetuating a vision of judging which requires freedom from the emotional response char-

15. See Judicial IndePEndEnce at the Crossroads: An InTERdisciplinary APPROACH (Stephen B. Burbank \& Barry Friedman eds., 2002); Gordon Bermant \& Russell R. Wheeler, Federal Judges and the Judicial Branch: Their Independence and Accountability, 46 MerCER L. REv. 835, 836-38 (1995); Archibald Cox, The Independence of the Judiciary: History and Purposes, 21 U. DAYTON L. REv. 565 (1996); Richard A. Epstein, The Independence of Judges: The Uses and Limitations of Public Choice Theory, 1990 BYU L. REv. 827 (1990); Pamela S. Karlan, Judicial Independences, 95 GEO. L.J. 1041 (2007); Symposium, Judicial Independence and Accountability, 72 S. CAL. L. REV. 311 (1999).

16. See Alexander M. Bickel, The Least Dangerous Branch: The Supreme Court at THE Bar of Politics (1986); Barry Friedman, "Things Forgotten" in the Debate Over Judicial Independence, 14 GA. ST. U. L. REv. 737 (1998). 
acteristic of the political process. It has also overlooked the way in which the Code of Judicial Conduct has contributed to a bureaucratic understanding of the judiciary as a distinct branch of government. By exploring the history of judicial courtesy and explaining the persistence of this understanding of the judicial role, this Article helps uncover alternative definitions of independence, which serve to promote, rather than undermine, judicial quality.

\section{I. \\ THE EARLY HISTORY OF JUDICIAL INDEPENDENCE, THE ROLE OF JUDGES, AND THE COURTESY RULES}

In colonial times, when judicial independence primarily meant independence from the Crown, judicial personality was given relatively free play. After the Revolution and roughly until the Civil War, a pragmatic approach to judging coexisted with the faith in natural law, and courts remained unconcerned about the effects of individual judges' emotions and personalities on performance of the judicial function. This changed, however, with the Civil War, which raised challenges to the courts' legitimacy centered on the perceived political nature of judicial lawmaking. In response, the idea of judicial independence expanded to focus on the courts' independence from the people and from their incursions through legislation. Seeking to recapture public respect, courts and commentators began to promote a formalistic theory of judging premised on the idea that judges reach inevitable results through the application of pure reason. Eliminating expressions of individual judges' sentiment and emotion from the performance of their work was important to reinforce this conception. Thus, the idea of judicial courtesy as an aspect of impersonal decision making was a break from the past that found its roots in a new understanding of judicial independence and a new rationale for preserving it.

\section{A. The Beginnings: Colonial and Frontier Judging}

Even in the colonial period, observers recognized the importance of an independent judiciary. ${ }^{17}$ As one pamphlet put it: "The men therefore who are to settle the contests between prerogative and liberty, who are to ascertain the bounds of sovereign power and to determine the rights of the subject, ought certainly to be per-

17. For the origin of the idea of judicial independence, see Irving $R$. Kaufman, The Essence of Judicial Independence, 80 CoLUM. L. REV. 671, 672-87 (1980). 
fectly free from the influence of either."18 While judges were largely free from the influence of the Crown, they were in some ways beholden to town representatives, who controlled their salaries. ${ }^{19}$ Colonists did not, however, seem overly concerned about this potential pressure on judicial independence. ${ }^{20}$ Their concern was with the perils of a judiciary that was excessively beholden to the executive. ${ }^{21}$

It is evident, even from the sparse historical record, that the experimental nature of colonial courts required a spontaneous and flexible style of judging. Most colonies developed an informal law that was easy to understand. The New England colonies adapted English law and procedure to the new setting, consciously moving away from the strict formal and elaborate rules. ${ }^{22}$ In some colonial courts, litigants would choose their own judges to hear their casesan arbitration of sorts. ${ }^{23}$ In New England, courts functioned much like church congregations or town meetings, navigating everyday disputes between neighbors in communities which, for the most part, shared common sets of values. ${ }^{24}$ On the frontier, justice was

18. A Letter to the People of Pennsylvania, \&cc, in 1 Pamphlets of THe AmerICAN Revolution, 1750-1776, at 257 (Bernard Bailyn ed., 1965).

19. Id. at 262, 268.

20. Charles G. Geyh, Judicial Independence, Judicial Accountability, and the Role of Constitutional Norms in Congressional Regulation of the Courts, 78 IND. L.J. 153, 161 (2003). 262.

21. Id. at 167; A Letter to the People of Pennsylvania, \&cc, supra note 18, at

22. Lawrence M. Friedman, A History of american law 45 (2d ed. 1985).

23. Id.; William E. Nelson, Dispute and Conflict Resolution in Plymouth County, MAssachusetTs, 1725-1825 (1981). Each precinct in Pennsylvania, for instance, appointed three persons known as "Common Peacemakers," who would referee all disputes without appeal to governor or council. LARRY A. BAKKEN, JUStice in the Wilderness: A Study of Frontier Courts in Canada and the United StATES, 1670-1870, at 88 (1986).

24. Morton Horwitz, The Transformation of American Law, 1780-1860 (1977); NELSON, supra note 23, at 134. Typical cases involved debts, slander, moral offenses, trespass, and breaches of Sabbath laws. See, e.g., Friedman, supra note 22, at 31-105 (discussing the structure and the role of courts in the colonies). Many magistrates had never practiced law, and some governors served, part-time, as chancellors. Id. at 125. Many of these lay judges had been politicians or served in the military. They populated all levels of the judiciary, including appellate courts. William E. Nelson, Americanization of the Common law: The Impact of Legal CHANGe ON MASSACHUSETTS SOCIETY, 1760-1830, at 33 (1994). In keeping with a long tradition in England, the key to becoming a magistrate was not a background in the law, but rather status in the community. Most judges were prominent local citizens who had either been born into an important family or who had achieved status through public service. Id. 
especially informal. ${ }^{25}$ Rudiments of the English system were imported, tested, and altered if they did not suit the surroundings. ${ }^{26}$ Magistrates, who lacked a "professional touch," 27 responded to necessity in a personal way in order to resolve the disputes before them. ${ }^{28}$

With little responsibility for interpreting or creating law, judges frequently confronted situations that required improvisation. They mediated more than they presided. They improvised justice rather than applying a set body of law. They were active, not in the contemporary sense of overruling legislative judgment or interpreting precedent broadly, but rather in the common meaning of that term, playing an active role in negotiating between parties, devising punishments, and monitoring compliance with court orders. One might easily conclude that such tasks required assertion rather than suppression of judicial personality.

\section{B. Reason and Emotion: Judging from the Revolution to the Civil War}

The years leading up to the Revolution saw a growing concern about the independence of the judicial branch from the executive. With the early republican fervor, few thought to suggest that the judiciary ought to be independent from the people. In the wake of the Revolution, however, after experiencing what some considered the extreme redistributive impulses of state legislatures, many critics grew wary of the whims of the popular will and, therefore, began to affirm the importance of a judiciary independent from both the executive and legislative branches. ${ }^{29}$ This notion of judicial independence embraced individual as well as branch independence.

25. See BAKKEN, supra note 23.

26. FRIEDMAN, supra note 22, at 45.

27. Colonlal Justice in Western Massachusetts (1639-1702): The Pynchon Court Record 31 (John H. Smith ed., William Nelson Cromwell Foundation 1961). Pynchon was responsible for establishing the first court and administering justice in western Massachusetts between 1640 and 1651 . Unlike most of his contemporaries, Pynchon kept meticulous records, which have survived and are compiled in this volume.

28. For example, William Pynchon, a justice in western Massachusetts between 1640 and 1651, described one incident, oddly foreshadowing modern case management, in which he urged a litigant who contested the validity of a jury verdict to ask his adversary to consent to a new jury trial by "indifferent men anywhere in the River." When the malcontent litigant rejected Pynchon's admonitions and instead simply refused to pay the judgment against him, Pynchon issued a warrant for his arrest. Id. at 207-08. Matters concerning Indians similarly pushed judges to favor expediency over rules and forms. See id. at 223.

29. See The Federalist No. 78 (Alexander Hamilton); Larry D. Kramer, The People Themselves: Popular Constitutionalism and Judicial Review 73 (2004); 
Individual judicial independence, in civic republican terms, denoted the financial freedom necessary to be virtuous and suppress self-interest for the sake of the common good. ${ }^{30}$ Because the threat to judicial independence came primarily in the form of legislative manipulation of judicial tenure and salary, the delegates to the Constitutional Convention adopted judicial tenure and salary protections. ${ }^{31}$ Independence was not an end in itself; it was a means to ensure that judges would correctly ascertain the meaning of the law and the just result without being swayed by a need to secure money or favors. ${ }^{32}$

After the election of 1800 , Jefferson and his allies fought against the Federalist judiciary. ${ }^{33}$ They challenged the idea of a judiciary independent from the people, arguing that the government should be entrusted to the people rather than removed from their control. In response, the Federalists, wary of the unchecked passions of the people, argued more vehemently that an independent judiciary was necessary to curb popular excess. ${ }^{34}$ As the Federalists defended their ground, they expanded the concept of independence to include freedom from the sway of transient legislative majorities. ${ }^{35}$ The perceived source of this new form of independence

Gordon S. Wood, The Greation of the American Republic, 1776-1787, at 436 (1969).

30. WooD, supra note 29, at 452; Geyh, supra note 20, at 159. As Alexander Hamilton wrote, "[A] power over a man's subsistence amounts to a power over his will." The Federalist No. 79, at 472 (Alexander Hamilton) (Clinton Rossiter ed. 1961). Generally, the founders assumed that if a judge possessed the requisite financial and professional security, he would necessarily act in such a way to preserve the independence of the judicial branch. See Geyh, supra note 20, at 159; A Letter to the People of Pennsylvania, \&cc, supra note 18, at 268-69. In other words, personal independence secured through salary and tenure protections would allow judges to suppress their own self-interest for the good of the community.

31. Charles Gardner Geyh, When Courts \& Congress Collide: The StrugGLE fOR CONTROL OF AMERICA's Judicial System 24-43 (2006). Article III provided, "The Judges, both of the supreme and inferior Courts, shall hold their Offices during good Behaviour, and shall, at stated Times, receive for their Services a Compensation, which shall not be diminished during their Continuance in Office." U.S. Const. art. III, $\$ 1$.

32. Wood, supra note 29 , at 538.

33. Right before his term ended, John Adams passed the so-called Midnight Judges Act, which created more federal judgeships, which Adams then quickly staffed with partisan allies. The Jeffersonians spent much of the first years of the nineteenth century trying to disestablish the courts and remove the objectionable judges. Friedman, supra note 22, at 127-28.

34. Barry Friedman, The History of the Countermajoritarian Difficulty, Part One: The Road to Judicial Supremacy, 73 N.Y.U. L. REV. 333, 360-62 (1998).

35. See id. at 361 . 
shifted from financial security to the fixed nature of the law. Based on their ability to discern and elaborate set principles of law, Federalists argued, judges could maintain a middle ground between the people and those who governed them. ${ }^{36}$ Swayed neither by the trappings of power nor the emotions of the crowd, the ideal judges possessed a kind of dignity that put them above the impetuous responses of the average citizen. ${ }^{37}$

While politicians fought over the role of the judiciary, courts and the nature of judging itself changed. By the middle of the eighteenth century, courts were beginning to move from the simple to the complex. English forms, models, and terms gradually infiltrated the colonies in New England. ${ }^{38}$ Economic expansion demanded more uniformity and stability in the law, and judges responded by deciding issues of law, leaving only factual disputes to the jury. ${ }^{39}$ Economic growth brought increasingly complex cases before the courts, and the outcomes could affect the course of social change. ${ }^{40}$ Judges became policymakers in addition to arbiters between disputing parties. They played a greater role in fashioning the law that mattered, defining rights in real property, the law of negligence, business contracts, and commercial instruments. ${ }^{41}$ The common law, which previously had been viewed as a fixed body of principles used to resolve disputes between individuals, came to be seen as an evolving agent of change. ${ }^{42}$ Judges' roles changed accordingly, and the judiciary gradually grew more professional. Trained in law, judges began to criticize the casual form of justice of the earlier colonial courts. ${ }^{43}$

36. See id. at 359.

37. WoOd, supra note 29 , at 452.

38. Friedman, supra note 22, at 48.

39. Nelson, supra note 23, at 165-74.

40. See generally Bruce H. ManN, Neighbors and Strangers: Law and CommuNITY IN EARLY CONNECTICUT (1987) (arguing that in the first half of the nineteenth century, the legal profession developed an autonomous system of law that was distinct from the individual disputes before courts).

41. Horwitz, supra note 24, at 2; James Willard HuRst, The Growth of American Law: The LaWmakers 185 (2001); William P. LaPiana, Logic and ExPErience: The Origin Of American Legal Education 4-5 (1994).

42. HoRwITz, supra note 24 , at 4; HuRst, supra note 41 , at 185 (discussing the courts "fashioning a body of common law for the main affairs of everyday life"); William J. Novak, The People's Welfare: Law and Regulation in NineteenthCentury America 40 (1996).

43. See Emory Washburn, Sketches of the Judicial History of MassachuSETtS: From 1630 to the ReVOLUTION IN 1775, at 189-90, 201-02 (1840). 
On one level, legal thinkers embraced the new role of judges as agents of social change. ${ }^{44}$ But at the same time, they retained faith in natural law as the source of common law. ${ }^{45}$ In either case, the process of administering the law and the ideology of how it worked allowed room for the creative and individual input of the judge. In the early nineteenth century, trial court judges still played an active part in resolving disputes and enforcing societal values. They understood their own role as ensuring the correct or just result, and they engaged in a casual and informal dialogue with the jury to encourage that outcome. ${ }^{46}$ As most jurists saw it, impartiality and independence entitled judges not simply to decide issues of law but also to direct and often determine the outcome of any case, preserving justice from the corrupting influence of partisan lawyers and a malleable jury. ${ }^{47}$

Like most nineteenth-century intellectuals, jurists drew a sharp distinction between reason and emotion. ${ }^{48}$ While they agreed that the process of judging should never be "mechanical," they believed reason rather than emotion ought to drive the judge. ${ }^{49}$ But no one thought that judges were without affect altogether, nor, more importantly, that emotion was absent from the process of judging. While jurists argued that decisions should be delivered with resort to pure intellect, they also insisted that judges be passionate in their devotion to justice. Horace Binney, a well known lawyer, statesman, and orator, described William Tilghman, Chief Justice of the Pennsylvania Supreme Court, as the perfect balance of these qualities:

44. Horwitz, supra note 24, at 1-30. Horwitz argues that by the end of the eighteenth century, legal thinkers had embraced an instrumental notion of the law, abandoning the assumption that judges find the law in favor of the conclusion that judges make the law. Id. He concludes that judges exercised this power to benefit the emerging commercial interests as well as the interests of the legal profession generally. Id. at 253-54, 256-57.

45. See Stephen M. Feldman, From Pre-Modern to Modern Jurisprudence: The Onset of Positivism, 50 VAND. L. REv. 1387, 1394-1411 (1997) (arguing that in the early nineteenth century, the instrumental approach to judging was consistent with faith in natural law).

46. Renee Lettow Lerner, The Transformation of the American Civil Trial: The Silent Judge, 42 WM. \& MARY L. REv. 195, 206-07 (2000).

47. Id. at 212.

48. Douglas T. Miller, The Nature of Jacksonian America (1973).

49. As United States Supreme Court Justice William Johnson said, "[i]t is the unenvied province of this Court to be directed by the head, and not the heart. In deciding upon principles that must define the rights and duties of the citizen and direct the future decisions of justice, no latitude is left for the exercise of feeling." The Rapid, 12 U.S. (8 Cranch) 155, 164 (1814). For the sharp distinction between intellect and emotions in nineteenth-century thought, see MLLER, supra note 48. 
"The law was his master; he yielded implicit obedience to its behests. Justice was the object of his affections; he defended her with the devotion of a lover." 50 While there was a sharp divide between reason and emotion, the ideal judge properly balanced both rather than embodying only the former.

In this era, when judicial personality, emotion, and creative personal engagement were still considered important aspects of judging, courtesy was an aspiration but never an invariable expectation even for the best judges. Praising Tilghman for his emotional commitment to justice, Binney wrote: "[N] $[$ othing could rouse his kind and courteous temper into resentment, more than a deliberate effort to entangle justice in the meshes of chicane." 51 While acknowledging that "[i] t argues little against the Judge or the advocate, that ... there should be momentary lapses of the temper,"52 he noted that Tilghman always remained courteous. ${ }^{53}$

\section{Mechanical Judging: From Reconstruction to the Progressive Era}

After the Revolution, the demand grew for the codification of all laws. ${ }^{54}$ Reflecting the faith in popular sovereignty, reformers hoped to transform the judge into "mere machine" by ensuring that "judges follow the letter of the law." 55 This, according to the proponents of codification, was the only way to prevent the people from becoming "slaves to the magistrates." 56 The codification movement faltered, ${ }^{57}$ but the underlying distrust of the judiciary remained and made its way into understandings of judicial independence and accountability. ${ }^{58}$ Particularly, the image of the ideal judge as machine permeated conceptions of independence even as the codification movement subsided. ${ }^{59}$

50. Horace Binney, Eulogies Upon Willlam Tilghman and John Marshall 23 (1861).

51. Id.

52. Id. at 34 .

53. Id. at 35 .

54. See David Dudley Field, Reform in the Legal Profession and the Laws, Address to the Graduating Class of the Albany Law School (March 23, 1855), in 1 Speeches, Arguments, and Miscellaneous Papers of David Dudley Field 494, 503-14 (A.P. Sprague ed., 1884).

55. WOOD, supra note 29, at 300-01 (citations omitted).

56. Id.

57. Friedman, supra note 22, at 403-07; see also Charles M. Cook, The Amertcan Codification Movement: A Study of ANTEbellum Legal. Reform 103-06, 201 (1981).

58. Geyh, supra note 20 , at $154-79$.

59. See Friedman, supra note 22, at 403-07. 
At the same time, Andrew Jackson's call for direct democracy brought new energy to the assault on the judicial branch.60 As the Civil War approached, more and more states elected their judiciaries. ${ }^{61}$ The earlier concern about judicial independence from the transient mood of the populace subsided as the prevailing democratic theory promoted a more popular form of democracy. ${ }^{62} \mathrm{Re}-$ formers urged that an elected judiciary would be independent from the political branches precisely because of its new accountability. ${ }^{63}$ The rise of party politics, in part, discredited the appointment system. ${ }^{64}$ If judges were directly elected, the argument ran, the population would ensure a judiciary whose opinions reflected justice rather than the whims of "broken down politicians."65 The same impulse led to evidentiary reforms that prohibited judges from commenting on evidence to influence jury deliberations. ${ }^{66}$ The reform movement, however, never caused a crisis of legitimacy for the courts because, to a great extent, people still believed that there was a set of determinate answers to all legal questions. ${ }^{67}$ Courts might have been overstepping their proper bounds by addressing political questions, but there was no real basis to question the underlying legitimacy of those bounds. ${ }^{68}$

As the Civil War approached, however, the perceived distinction between law and politics began to break down. The country split increasingly over the issue of slavery, and many turned to the courts to resolve the question. ${ }^{69}$ For the most part, judges, who were motivated by a largely instrumental view of the law, rejected the rhetoric of the anti-slavery movement by appealing to the prac-

60. While some of the critique focused on the lack of accountability, most reformers of the time argued against judicial supremacy rather than focusing on the countermajoritarian difficulty. Friedman, supra note 34, at 392-93.

61 . Geyh, supra note 20 , at 170.

62. See GEYH, supra note 31, at 55-56; Caleb Nelson, A Re-Evaluation of Scholarly Explanations for the Rise of the Elective Judiciary in Antebellum America, 37 AM. J. LEGAL HIST. 190, 190 (1993).

63. Nelson, supra note 62 , at $195-96$.

64. See id. at 196.

65. Id.

66. See Lerner, supra note 46 , at 220-21.

67. HoRWITZ, supra note 2, at 10; Geyh, supra note 20, at 179-88.

68. See Friedman, supra note 34, at 405-06.

69. See Don E. Fehrenbacher, The Slaveholding Republic 195-200 (Ward M. McAfee ed., 2001) (describing the treatment of federal cases involving the slave trade from 1842 through 1862 , and noting that such treatment varied highly by region). See generally Thomas D. Morris, Southern SLAvery and the Law, 1619-1860 (1996) (discussing court decisions in the South leading up to the Civil War as one of the main sources of slavery law). 
tical need to maintain the union. ${ }^{70}$ In the aftermath of the Civil War, Northerners criticized courts for abandoning principle in favor of such instrumental concerns. ${ }^{71}$ Pointing in particular to Dred Scott, reformers argued that antebellum courts had devolved into tools for a particular political agenda. ${ }^{72}$ Courts and scholars responded to this crisis by identifying a new source of legitimacy for the courts based on orthodox, or classical, legal theory, which posited a system of laws separate from both politics and morality. ${ }^{73}$ Rather than follow the whims of a particular political faction or the mandates of expedience, jurists drew on the late-nineteenth-century infatuation with science to elaborate a new formalist jurisprudence. ${ }^{74}$ According to this jurisprudence, classification, systematization, and a particular form of deductive reasoning set the law apart from morality and politics. The common law judge was thus engaged in the process of locating preexisting principles. ${ }^{75}$ Even if such principles had never been formulated, they were believed to exist independent of any particular case. ${ }^{76}$

As formalism replaced the instrumental reading of the law and any residue of the natural law tradition, the image of the judge underwent its own revision. ${ }^{77}$ Law as science required objective out-

70. William E. Nelson, The Impact of the Anti-Slavery Movement Upon Styles of Judicial Reasoning in the Nineteenth Century, 87 HARv. L. REv. 513, 538-39 (1974).

71. Id. at 544-50.

72. Id.; Friedman, supra note 34 , at 414.

73. See William M. Wiecek, The Lost World of Classical Legal Thought: LAW AND IdeOloGY IN AMERICA, 1886-1937, at 12 (1998).

74. Id. at 91 .

75. Id. at $98-100$.

76. Id.

77. There is some disagreement over the extent to which judges and lawyers understood their roles as applying natural law as opposed to embracing an instrumental view of the law. Compare G. Edward White, Judicial Activism and the Identity of the Legal Profession, in Intervention and Detachment: Essays in Legal History AND JURISPRUDENCE 222, 225-26 (1994) (describing nineteenth-century legal theory as limiting judges' role to that of enforcing an objective body of discoverable principles), and LAPIANA, supra note 41, at 29-38 (arguing that nineteenth-century legal thought emphasized law as a science of natural principles), with Horwrr, supra note 24, at 30 (depicting legal theory in the nineteenth century as embracing law as a means of bringing about social change), and Robert W. Gordon, Critical Legal Histories, 36 STAN. L. REv. 57, 59-67 (1984) (describing dominant vision of law as facilitating natural evolution of society towards progressive goals), and Grant Gilmore, The Ages of American Law 77 (1977) (claiming that because of the uncertainty in law, judges inevitably considered impact on social or economic conditions in formulating common law). For an effort to reconcile these two positions, see Feldman, supra note 45, at 1404-08. For the purposes of this Article, it is important that judges at the very least used natural law rhetoric to justify their role, instrumental or otherwise. 
comes, independent of the person whose job was to implement it. ${ }^{78}$ The ideal of a judge whose passion for justice drove his rational understanding of the law gave way to a vision of a judge who set emotion aside and relied entirely on reason to achieve the proper result.

This new formalism was built around the idea of law as science. ${ }^{79}$ Precedent, like facts, could be sorted and classified so that every decision would flow ineluctably from those that came before it. Principles could be deduced from cases and applied to new cases to reveal the necessary and appropriate outcomes. ${ }^{80}$ Those who embraced the scientific view of the law believed that they could, and indeed must, extricate idiosyncrasies of the human mind, rendering the process of judging scientific and predictable. ${ }^{81}$

This formalistic view of the law made the distinction between reason and sentiment more pronounced. While a few decades earlier the perfect judge was believed to balance reason with a passion for justice, post-Civil War jurists placed a new premium on reason standing alone. In other words, they believed passion and emotion had no place in the law. As the Supreme Court put it in 1866:

During the late wicked Rebellion, the temper of the times did not allow that calmness in deliberation and discussion so necessary to a correct conclusion of a purely judicial question. Then, considerations of safety were mingled with the exercise of power; and feelings and interests prevailed which are happily terminated. Now that the public safety is assured, this question, as well as all others, can be discussed and decided without passion or the admixture of any element not required to form a legal judgment. ${ }^{82}$

Similarly, in an 1896 discussion of the rules prohibiting judges from commenting on evidence, the Court maintained that judges must heed "the line which separates the impartial exercise of the judicial function from the region of partisanship where reason is disturbed, passions excited, and prejudices . . . necessarily called into play."83 In drawing the stark divide between reason and passion, the Court equated emotion with bias. The Court resorted to this dichotomy not only for practical purposes but also to draw a

78. HoRWTTZ, supra note 2, at 9-10.

79. See WIECEK, supra note 73, at 91; Nelson, supra note 70 , at 560-64.

80. WIECEK, supra note 73 , at 91 .

81. Id.

82. Ex Parte Milligan, 71 U.S. (4 Wall.) 2, 109 (1866).

83. Hickory v. U.S., 160 U.S. 408, 425 (1896). 
distinction between the judiciary and the political branches while justifying and exalting the former. ${ }^{84}$

Ironically, but perhaps not incidentally, the image of the judge as mechanical, deciding cases without resort to emotion or personal opinion, intensified just as judges were entrusted with more power. Part of preserving predictability in the law involved shifting decisions from jury to judge. ${ }^{85}$ Thus, late-nineteenth-century formalism favored objective over subjective tests, abandoning fact-intensive inquiries into the intentions of the parties and relying on legal standards of what a reasonable person would have intended. ${ }^{\mathbf{8 6}}$ These standards meant that more issues were decided by judges as matters of law rather than by juries as questions of credibility or fact. ${ }^{87}$

In its effort to mechanize the law, post-Civil War formalism banished passion and emotion from the process. ${ }^{88}$ As Cyrus Northrop, a post-war conservative lawyer and scholar, explained: "Passion may clamor as it often does, for ex post facto laws, for laws which involve a violation of the obligation of contracts, or for laws which impair freedom of thought or speech or religion; but the Courts throw all such laws out as fast as an abnormal legislature can pass them." 89 Picking up and running with the secondary meaning of

84. See, e.g., Hilton v. Guyot, 159 U.S. 113, 220 (1895) (in deciding what force and effect to give to foreign judgments, the Court discusses various approaches taken by foreign nations, including, in the absence of a governing treaty, why the judiciary rather than the executive is best suited to determine if reciprocity exists between the courts of different nations).

85. HoRWTTz, supra note 24, at 28-29.

86. Id. at 197-98.

87. See William M. Wiecek, The Reconstruction of Federal Judicial Power, 1863-1875, 13 AM. J. LEGal Hist. 333, 339 (1969).

88. The shift from an agricultural to an industrial economy, the migration to the cities, the rush of women workers into the market, immigration, and emancipation all seemed to bode ill for the security of both the new and the old American elite. See, e.g., Alice Kessler-Harris, OUt of Work: A History of Wage-Earning Women in the United States 75-110 (1982); Joanne J. Meyerowitz, Women AdRIFT: INDEPENDENT WAGE EARNERS IN CHICAGo, 1880-1930, at 140 (1991); DAVID F. Noble, America by Design: Saience, Technology, and the Rise of Corporate Capitalism 58 (1977); Robert Wiebe, The Search for Order, 1877-1920, at 12-21 (1967). The series of economic depressions culminating in the Panic of 1893 were followed by serious labor unrest, which in turn invited a massive display of government force, fueling the sense of unease. See, e.g., Dand Montcomery, The Fall of the House of Labor: The Workplace, the State, and American LABOR ACTIVISM, 1865-1925, at 48, 346 (1987). Formalists reacted with a system of thought designed to impose order on the chaos. See, e.g., Horwitz, supra note 2, at 188; WIEcEK, supra note 73, at 123-24.

89. Cyrus Northrop, The legal Profession as a Conservative Force in our Republic, An Address Delivered Before the Graduating Classes at the 
judicial independence developed after the Revolution, namely that judges should stand above the popular fray, courts and judges grew to stand for reason against passion, for a salutary break on the mindlessness of the mob. ${ }^{90}$ By branding the legislature both "passionate" and "abnormal," Northrop equated legislative passion with disease, and the law, stripped of all emotion, with the cure. ${ }^{91}$ Judicial decisions were seen to "come like the answer to an algebraic problem without partiality, even as the unknown quantities in the problem are subjected to the operation of undeviating mathematical principles in order to determine their value."92 Predictability became the goal of the legal system, and any display of emotion by judges was seen as anathema.

In this world, judges became human calculators, and justice depended on the complete suppression of all idiosyncratic personality that might interfere with this pristine process:

If there is any departure from this absolute impartiality and impersonality in the administration of justice, it is no fault of the system, no fault of the law, but the fault of the men who represent and administer justice, either because they are unworthy to preside in the temple of justice, or, being worthy, they are yet incapable of becoming mere intellectual and judicial machines, but are men still in spite of being judges. ${ }^{93}$

Thus, passion, emotion, and personality in a judge grew to represent the very forces threatening to destroy judicial independence as it had come to be defined under formalist theory. ${ }^{94}$ In particular, passion, emotion, and personality represented the prejudices and infirmities of the people as opposed to the wisdom embodied in reasoned application of the law.

Under the new formalist jurisprudence, judicial independence grew to denote the special role of the judicial branch defined by its special form of legal reasoning. The individual independence of judges now required not simply financial security but the suppression of passion and personality. This remained a necessary condition to the independence of the branch. The judiciary would be distinct from the political branches precisely because judges were able to ascertain the meaning of the law by suppressing their own

Sixty-Eighth Anniversary of Yale Law School (June 28th, 1892), reprinted in ADDResses: Educational and Patriotic 90 (1910).

90. See supra notes 33-37 and accompanying text.

91. NORTHROP, supra note 89 , at 90 .

92. Id. at 91.

93. Id. at 91-92.

94. Id. 
presuppositions. Such suppression necessarily promoted the independence of the judicial branch by demonstrating its distance and immunity from the other two branches.

According to formalist legal theory, " $[\mathrm{t}]$ he distinction between a judicial and a legislative act is well defined. The one determines what the law is, ... the other prescribes what the law shall be ..."95 Thus, the very nature of legal reasoning, the special scientific field devoted to discerning the meaning of the law, became the guarantee of independence for the judicial branch. Only the legislature was entitled to consider the "abstract justice and equity" of a situation while " ‘[j] ustice and equity,' for the courts, mean merely conformity to the law."96 In this world, impartiality (defined as impersonality) was a necessary prerequisite to judicial independence not only because it allowed the individual judge to properly determine the just result, but also because it allowed the judicial branch to perform its job of determining the meaning of existing law.

II.

THE APPEARANCE OF IMPARTIALITY: THE CANONS OF JUDICIAL ETHICS

In the early part of the twentieth century, an elite group within the bar used pronouncements about judicial ethics and judicial courtesy to convince the general population that judges were, in fact, impartial. Thus, the Canons of Judicial Ethics, published in 1924, became a way to counter growing critique that judges were merely partisans in an increasingly hostile class war. ${ }^{97}$ By urging judges to be courteous, the drafters argued, the Canons would help convince skeptics that judges were mechanically applying set law in a scientific fashion rather than drawing on their own class biases to rule in favor of one set of interests against another. The Judicial Canons responded to a perceived crisis in confidence in the judiciary. The Canons' emphasis on the appearance of impartiality generally and judicial courtesy in particular seemed the proper remedy.

95. William Hamilton Cowles, The Distinction Between Legislative and Judicial Power, 40 AM. L. ReG. 433, 437 (1892) (quoting The Sinking Fund Cases, 99 U.S. 700, 761 (1878) (Field, J., dissenting)).

96. Id. at 444 .

97. 48 A.B.A. Rep. 452-60 (1923); Canons of Judicial. Ethics (1924). 


\section{A. Perceived Crisis in the Legitimacy of the Courts}

Formalism, with its theory of a superhuman judicial machinery, did not last very long. Almost from its inception, the idea of a coherent, predictable legal science caved under the pressure of its own inconsistencies. All it took was a few intelligent critics at the end of the nineteenth and the beginning of the twentieth centuries to reveal the internal contradictions. ${ }^{98}$ Following the early steps of Oliver Wendell Holmes, Jr., progressive legal reformers demonstrated that law was not a science, and the premises of legal formalism could not hold. The judge's policy preferences, his intuitive sense of justice, and equities of the case always played a pivotal role. ${ }^{99}$

In 1881, Holmes began his book The Common Law with the phrase " $[t]$ he life of the law has not been logic; it has been experience." 100 By 1897, Holmes' theory of the law had matured, as he argued that almost all judicial decisions previously understood as dictated by logic were, in fact, driven by legislative policy: "I think that the judges themselves have failed adequately to recognize their duty of weighing considerations of social advantage. The duty is inevitable ...."101 In 1913, Wesley Newcomb Hohfeld published a highly influential article in the Yale Law Journal explaining that not all legal relations are capable of being reduced to discrete categories. ${ }^{102}$

Central to this mounting critique of classical jurisprudence was a growing conviction that judges exercise discretion in determining cases; they do not simply apply the law in a mechanical fashion but rather create it. Benjamin N. Cardozo gave a moderate voice to this critique in a series of lectures at Yale, which were ultimately published as a single volume in 1921. Cardozo criticized legal formalism, acknowledging that he accepted "judge-made law as one of the existing realities of life." $103 \mathrm{He}$ reconciled this observation with the rule of law by concluding,

98. See Horwitz, supra note 2, at 53; Laura Kalman, Legal Realism at Yale, 1927-1960, at 49-54 (1986). See generally Purcell, supra note 2, at 74-94; JoHN Henry Schlegel, American legal Realism and Empirical Social Science (1995). 99. See Joseph C. Hutcheson, Jr., The Judgment Intuitive: The Function of the "Hunch" in Judicial Decision, 14 CoRNELl L. Q. 274 (1929).

100. Oliver Wendell Holmes, Jr., The Common Law 1 (1891).

101. Oliver Wendell Holmes, Jr., The Path of the Law, 10 Harv. L. Rev. 457, 467 (1897).

102. Wesley Newcomb Hohfeld, Some Fundamental Legal Conceptions as Applied in Judicial Reasoning, 23 YALE L.J. 16, 28-32 (1913).

103. Benjamin N. Cardozo, The Nature of the Judicial Process 10 (1921). 
The eccentricities of judges balance one another. One judge looks at problems from the point of view of history, another from that of philosophy, another from that of social utility, one is a formalist, another a latitudinarian, one is timorous of change, another dissatisfied with the present; out of the attrition of diverse minds there is beaten something which has a constancy and uniformity and average value greater than its component elements. ${ }^{104}$

Pragmatism and a kind of social Darwinism affected not only the jurisprudential debate but also the image of the ideal judge. ${ }^{105}$ By 1929, Joseph C. Hutcheson took this assumption to its logical conclusion: "to ... great judging, the imaginative, the intuitional faculty is essential." 106

Just as the early Realists were exposing the faults in the intellectual structure of classical legal science, the courts were experiencing very practical incursions on their jurisdiction and threats to their legitimacy. The progressive reform movement comprised a fairly motley crew. Among its ranks were legal reformers who were committed not only to proving the errors of legal formalism's ways but also to the progressive social goals of the movement. ${ }^{107}$ Amidst the various reform agendas was an anti-corruption campaign that extended, in part, to the courts. ${ }^{108}$ Rather than policing abuses in party politics, the reformers insisted, judges had become part of the problem. As adamantly as jurists might insist on law as science and the rule of law as distinct from politics, the corruption scandals that

104. Id. at 177 .

105. See Andrew L. Kaufman, Cardozo 32, 39 (1998); Louis Menand, The Metaphysical Club 337-75 (2001) (explaining the intellectual roots of pragmatism).

106. Hutcheson, supra note 99 , at 288 . Drawing from this conclusion, Hutcheson suggested that law schools ought to devote more time to developing these faculties and understanding how they operate. The law and emotion "movement" has in a certain way taken up this task, devoting itself to the study of the role of emotion within the law, legal theory, and decision making. See Maroney, supra note 9 , at 121-23. 45-46.

107. See, e.g., HoRwitz, supra note 2, at 188, 210; KALMAN, supra note 98, at

108. Michael J. Powell, From Patrician to Professional Elite: The TransFORMATION OF THE New YORK CITY Bar Association 18-28 (1988). For a general discussion of progressive era reforms, see, for example, Allen F. Davis, Spearheads For Reform: The Social Settlements and the Progressive Movement, 1890-1914 (1984); Richard Hofstadter, The Age of Reform: From Bryan TO F.D.R 197 (1955); N.E.H. Hull, Reconstructing the Origins of Realistic Jurisprudence: A Prequel to the Llewellyn-Pound Exchange Over Legal Realism, 1989 DUKE L.J. 1302, 1307. 
dominated the headlines suggested that some judges were not only human but also tragically so. ${ }^{109}$ They were just as susceptible to bribes and promises of future rewards as any politician or civil servant. ${ }^{110}$

Perhaps the legal establishment could have lived with the theoretical assault on the purely scientific nature of the law, but reformers posed another, more direct threat to the authority of the judiciary. ${ }^{111}$ Drawing on their critique of formalism and promoting a particular political agenda, progressives attacked classical judges for striking down reform legislation. ${ }^{112}$ They argued that the courts had become tools of the new robber barons, facilitating the concentration of wealth and power at the expense of the less privileged. ${ }^{113}$ Insisting that judges consistently invalidated reform legislation under the guise of following the dictates of the Constitution, these reformers suggested that the people ought to have the final word. ${ }^{114}$ Thus, they introduced bills for judicial recall that imposed far greater review of judicial decisions, invalidated state statutes on constitutional grounds, and made it easier to remove a judge who issued that sort of decision. ${ }^{115}$ In Colorado, for instance, progressives successfully amended the state constitution to allow a popular vote to review any judicial opinion declaring a statute invalid under the state or federal constitution. ${ }^{116}$ It is no coincidence that in the year the Canons were published, Robert M. LaFollette ran for President on a platform attacking the courts. Labor groups and other progressive and populist groups rallied to the support of LaFollette, who called for an end to the "judicial oligarchy."117 Among other

109. See, e.g., Powell, supra note 108, at 6-7. See generally Renee Letow Lerner, From Popular Control to Independence: Reform of the Elected Judiciary in Boss Tweed's New York, 15 Geo. Mason. L. Rev. 109, 144-47 (2007).

110. See, e.g., Powell, supra note 108, at 6-7.

111. See Edward Purcell, Brandeis and the Progressive Constitution: Erie, the Judiclal Power, and the Politics of the Federal Courts in Twentieth Century America 20 (2000). See generally William G. Ross, A Muted Fury. Populists, Progressives, and Labor Unions Confront the Courts, 1890-1937 (1994).

112. See, e.g., Theodore Roosevelt, Judges and Progress, OurLook (N.Y.), Jan. 6, 1912 , at $42-44$.

113. See Powell, supra note 108, at 3-44.

114. See, e.g., Daniel W. Baker, The Recall of Judicial Decisions, 1 Geo. L.J. 2, 1-12 (1912).

115. See Charles A. Boston, Some Conservative Views on the Judiciary and Judicial Recall, 23 YALE L.J. 511, 511 (1914); Elihu Root, The Perils of Judicial Recall, 18 CASE \& COMMENT 308, 312 (1911) (arguing against a judicial recall provision).

116. Jesse G. Northcutt, The Recall in Colorado, 25 GrEEN BAG 372, 378 (1913).

117. LaFollette Lashes Federal Judiciary, N.Y. Times, June 15, 1922, at 1. 
things, LaFollette advocated recall of judicial decisions, including those of the United States Supreme Court. ${ }^{118}$ Conservative groups aligned with the bar in condemning his candidacy with horror and rage. ${ }^{119}$

\section{B. The Courtesy Rules as a Response to the Perceived Crisis in Legitimacy}

The decision to turn general principles into written guidelines was a reaction to the attack, which had precipitated a perceived crisis in the legitimacy of the judiciary. The Canons of Judicial Ethics affirmed the importance of judicial courtesy in order to create the appearance of an impartial judiciary. Despite the growing outcry against the courts, the authors and proponents of the Canons did not themselves believe that the independence and legitimacy of the judicial branch were in jeopardy. ${ }^{120}$ They nevertheless were resolute about the need to convince an impatient and impetuous public. They focused in important part on judicial demeanor as a way to project an impartial image. ${ }^{121}$

In January 1922, the American Bar Association ("ABA") created a committee to draft rules of professional conduct for judges. ${ }^{122}$ The Canons would be merely aspirational, and the leaders of the bar hoped they would provide guidance for judges while, more importantly, projecting a new, more wholesome image for the judiciary. The committee, chaired by Chief Justice William $H$. Taft, consisted of fairly conservative lawyers and judges. ${ }^{123}$ The following year, the committee drafted a set of thirty-four canons, which were approved with minor edits in 1924. ${ }^{124}$

The preamble to the Canons reflected the predominant philosophy of the ABA in general and the committee in particular. Beginning with excerpts from Francis Bacon's Essay on Judicature, the Canons embodied the older mechanical jurisprudence, which ex-

118. Id.

119. See Ross, supra note 111, at 273-74.

120. See infra notes 138-41 and accompanying text.

121. See infra notes $125-31$ and accompanying text.

122. 48 A.B.A. REP. 454-60 (1923); 49 A.B.A. REP. 67-71 (1924).

123. 48 A.B.A. Rep. 454. The American Bar Association appointed prominent members of the bench and bar: Leslie C. Cornish, Chief Justice of the Maine Supreme Court; Robert von Mosechzisker, Chief Justice of the Pennsylvania Supreme Court; Charles A. Boston, a prominent New York attorney; and George Sutherland. When President Warren Harding nominated Sutherland to serve as Associate Justice of the Supreme Court, he was replaced by Garret W. McEnerney, a leader of the San Francisco Bar.

124. Id. 
horted judges to be impartial, to suppress their individual personalities, and to find the preexisting law (not make it). ${ }^{125}$ The preamble drew on Bacon to translate this jurisprudence into a prescribed judicial style: "Judges ought to be more learned than witty; more reverend than plausible; and more advised than confident."126 The quotations elaborated: "Patience and gravity of hearing is an essential part of justice; and an over speaking judge is no well-tuned cymbal. It is no grace to a judge first to find that which he might have heard in due time from the bar . . .."127 Under the heading "Essential Conduct," Canon Six read: "He should be temperate, attentive, patient, impartial, and since he is to administer the law and apply it to the facts, he should be studious of the principles of the law and diligent in endeavoring to ascertain the facts." 128 Canon Eleven also urged a judge to be considerate of jurors and witnesses, and Canon Twelve, captioned "Courtesy and Civility," stated that judges should be courteous to counsel and others. ${ }^{29}$ The Canons consisted largely of rules of judicial demeanor, which would project impartiality and assure the public that judges were applying the law scientifically as opposed to deciding cases based on their own predilection.

The Canons affirmed the importance of judicial independence, defining it as freedom from the pressures of the public. Considerably less concerned about executive control over the judiciary, the Canons reflected a growing sense of independence as freedom from the unthinking trends of the masses. Canon Fourteen read: "Independence. A judge should not be swayed by partisan demands, public clamor, or considerations of personal popularity or notoriety, nor be apprehensive of unjust criticism."130 Canon Thirty-Four made this meaning even more explicit: "[A judge] should be . . . impartial, fearless of public clamor, regardless of public praise, and indifferent to private political or partisan influences." 131

The emphasis on courtesy grew directly from the older formalist judicial philosophy. The premise was that personality of a judge

125. Am. Bar Ass'N, Report of Committee on Judicial Ethics (1923) ("Judges ought to remember that their office is jus dicere not jus dare; to interpret the law, and not to make law, or to give law." (quoting Francis Bacon, Essay on Judicature)).

126. Id.

127. Id.

128. Id.

129. $I d$.

130. Id.

131. Id. 
should be excluded in the mechanical application of justice. Rejecting Cardozo's earlier insight, one proposed canon stated: "Justice should not be molded by the individual idiosyncrasies of those administering it." 132 The emphasis on ritual took on new urgency as its proponents perceived rapid changes in their environment. In 1924, Judge Caroll T. Bond of the Maryland Supreme Court noted:

And as men tend to harmonize with their surroundings and the attitude of others, we even have to keep up with care such things as parliamentary behavior in the courts, and for the upkeep small ceremonials may be of greater importance than we usually realize. The impersonal relation of the judge to the case before him is of very great importance, and some of us fear there may be a giving of ground in such a little thing as the drift toward direct personal address to the judge in the course of trial, which is sometimes seen in Baltimore City. ${ }^{133}$

The rules concerning judicial comportment, according to this judge, were more than mere etiquette guidelines. They compensated for the chaos and unfamiliarity of the new urban landscape. They warded off the alien cultures that came with it. Judge Bond contended:

The personal touch in judicature may be a blighting touch. Perhaps it is only by preserving the conception of a court of justice as something larger than the men who carry it on, as something which transcends them, and compels their reverence, that the ground gained through the centuries and left to us of the later generations, can be held secure. ${ }^{134}$

In other words, the rule of law ought to be more than the sum of its administrators. ${ }^{135}$ The perceived threat to the value of the judiciary along with the sense of instability generally prompted some to publicize this premise and project this conservative image in the form of the Canons of Judicial Ethics.

More than a reiteration of the formalist ideology, the Canons represented a response to the perceived attack on the legitimacy of the judicial branch. As one jurist put it: "The judicial functions, which until recently were regarded with a reverence approaching

132. Editorial, Proposed Canons of Judicial Ethics, 27 LAw Notes 1, 1 (1923); 9 A.B.A. J. 189, 191 (1923) (quoting Proposed Canons of Judicial Ethics Canon 21).

133. Judge Carroll T. Bond, The Growth of Judicial Ethics, Address before the Maryland State Bar Association (June 24, 1924).

134. Id.

135. Id. 
awe, are being subjected to sharp analysis and criticism."136 To counter the increasingly credible critiques by jurists like Holmes and popular figures like LaFollette, the appearance of impartiality was at least as important as impartiality itself. So Chief Justice William H. Taft wrote: "The appearance of justice in the courts, especially in these times when demagoguery and sincere ignorance are united in an unjust attack upon our courts, is profoundly necessary." 137 The Canons were designed in part as a public relations campaign. Its authors did not doubt, at least not out loud, that most judges were in fact impartial, interpreting and not inventing the law. Sensing, however, that they were losing ground, it appears they felt the need to project that reality by codifying it.

After launching a defense of the judiciary, its use of the injunction to prevent strikes and of the Fourteenth Amendment to invalidate reform legislation, Charles Boston, a prominent lawyer and member of the committee charged with drafting the Canons, explained:

It is not semi-monastic solitude, traditional veneration of the Constitution, or a natural instinct to preserve property rights, which has weakened the Judiciary, but the fact that the people were not individually impressed with the wonderful integrity, the amazing ability, the great industry and the utter impartiality of the Bench. ${ }^{138}$

The real problem, as Boston saw it, was that in their ignorance, people blamed the individual judge instead of the law. ${ }^{139}$ His choice of the word "bench" rather than judge is illustrative of his desire to render the process impersonal. According to Boston, the public blamed the courts because the public was unwilling to accept that the law, and the good of all, often favored the wealthy, more powerful classes. He argued that it is "easier to abuse a judge than to change a Constitution," 140 and believed that the crisis in the legitimacy of the judiciary was not a matter of judicial overreaching but rather the product of a few bad seeds ruining the image of the entire branch. He concluded that the bar needed rules that would

136. W.F. Dodd, Social Legislation and the Courts, 28 PoL. Scr. Q. 1, 1 (1913).

137. William H. Taft, Legal Ethics, 2 B.U. L. Rev. 71, 83 (1922).

138. Boston, supra note 115 , at 528 .

139. Id. at 512. Taft made the same argument in an article on the Federal Judiciary, claiming that people perceived the courts as taking sides in class warfare, when, in fact, they were merely interpreting a law that in the end served the interest of all classes. William H. Taft, Charges Against the Federal Judiciany, I VA. L. REG. 389, 411 (1895).

140. Boston, supra note 115 , at 520 . 
make even the bad judges look good. This, in turn, would make it more difficult for the public to confuse the harsh realities of the Constitution with judicial bias. ${ }^{141}$

In addition to the defense of formalism, the new Canons with their emphasis on judicial temperament and style sought to portray judges as gentlemen, a subtle but forceful rebuke to immigrants in both the legal profession and on the bench. ${ }^{142}$ Professor Jerome Auerbach has argued that the late-nineteenth-century bar was struggling to resist the implication of diversity among its ranks. ${ }^{143}$ The new wave of immigrants was not only joining the general population, it was also beginning to seep into the profession. Auerbach demonstrates that the bar fought hard to close ranks. It developed rules against advertising, contingency fees, and solicitation-all in a somewhat futile attempt to cleanse the profession of its new members. ${ }^{144}$

By attempting to banish emotional expression through rules against discourtesy and intemperance, the authors of the Canons were acting to exclude a more colorful style of judging associated with ethnic minorities. At the very least, it was fighting to guarantee that the ideal judge would not look like these newcomers. Thus, one commentator on the new Canons mentioned the importance of projecting an image of the judiciary as "gentlem[anly]."145 A judge explained it as follows:

Like a bishop, a judge should be the husband of but one wife, and of affinities he should be very wary. He should not lead the life of a roisterer, carouse in taverns or other questionable resorts, or associate with persons of known evil life. He should never seek political preferment while still occupying the bench. ${ }^{146}$

Reminiscent of images of the urban world with its political machines, this commentary picked up on the language of the moral

141. See id. at 527-28.

142. For a discussion of a similar effort to cleanse the bar of the new immigrant class, see Jerold Auerbach, Unequal. Justice: Lawyers and Social. Change in Modern America 43-49 (1976).

143. Id. at 106-30.

144. Id. at 43-48.

145. Russell Benedict, Ethics of the Bench, 8 A.B.A. J. 199, 201 (1922).

146. J. Jesse Holdom, The Ethics of the Bench, A Paper Read Before the Illinois State Bar Association at Chicago (June 25, 1908), in CHI. Legal News, June 27,1908 , at 369 . 
reform movement of the time, proselytizing middle-class mores as the solution to the urban iniquity spread by new ethnic groups. ${ }^{147}$

The campaign to portray judges as gentlemanly, impartial, and impersonal administrators of the law came just as the actual role of judges was moving in the opposite direction. Meeting the needs of turn-of-the-century urban America, trial judges began to play a more active and personal role in proceedings. ${ }^{148} \mathrm{New}$ sorts of trials and cases in the early part of the twentieth century began to replace simple disputes. The adversarial proceeding between two individuals grew to be the exception rather than the rule. ${ }^{149}$ Cases grew to be more complex, involving social welfare agencies, parole offices, corporations, and multiple groups of litigants. ${ }^{150} \mathrm{New}$ courts emerged at the turn of the nineteenth century that were designed to immerse themselves in a community and solve problems in a more holistic way. ${ }^{151}$ For example, the first juvenile court, which opened in Illinois in 1899, drew on the new social sciences to derive solutions to the difficult problems involving children in urban America. ${ }^{152}$ These changes demanded that judges play a more active and personal role in the proceedings. ${ }^{153}$ In the face of this new trend, the campaign to project an appearance of impartiality seems like a rearguard effort to resist the pressures drawing lower court judges into the turmoil.

In the 1920s, the judicial elite saw the Canons as a way of projecting an accurate image of the judiciary as a separate branch, retaining legitimacy because of the unique nature of legal reasoning. They believed that the Canons would cause the public to see what the authors already knew to be true: that judges, through their special training and abilities, discern the meaning of the law but do not make it. In other words, courts were seen as legitimate and independent because of the scientific nature of legal reasoning, which ensured a government of laws, not of men. In the 1920s, the image of a detached and impartial judge enshrined in the Canons served as a sign for the public that this was, indeed, the case.

147. See generally Paul Boyer, Urban Masses and Moral Order in America, 1820-1920 (1978).

148. See generally David S. Tanenhaus, Juvenile Justice in the Makinc (2004); Michael Willrich, City of Courts: Socializing Justice in Progressive ERA Chicago (2003).

149. See generally WILLRICH, supra note 148.

150. See generally id.

151. See generally id.

152. See Tanenhaus, supra note 148 , at xxiv.

153. See generally WILLRICH, supra note 148. 
III.

\section{THE BUREAUCRATIZATION OF THE JUDICIARY: THE 1972 CODE OF JUDICIAL CONDUCT}

Fifty years after the adoption of the Canons, in 1972, the ABA adopted the Code of Judicial Conduct to replace its earlier set of rules regarding judicial behavior. ${ }^{154}$ With the development of judicial branch self-regulation through the establishment of judicial commissions authorized to sanction individual judges for misconduct, the new rules were enacted to be enforceable, not merely advisory. Their adoption coincided with, and reflected, changing ideas of the judicial role and judicial independence.

By the 1970s, the jurisprudential tides had turned, and most jurists recognized that judges are involved in making the law, and that they bring to the bench ideologies, preconceptions, and intuitions. ${ }^{155}$ Most scholars, judges, and lawyers acknowledged that judicial reasoning was not categorically different from political reasoning. As one contemporary put it, " $[\mathrm{t}] \mathrm{o}$ continue to insist upon calling a judge a neutral automaton, when all human experience refutes that notion, is to be willfully blind." ${ }^{156}$ Rather than admit that moral authority derived from some source other than the special nature of legal reasoning, the bar in the early 1970s compensated for the loss of such absolutes with sociological rhetoric. Max Weber famously explained that bureaucratization involves the "abstract regularity of the exercise of authority."157 The 1972 Code of Judicial Conduct marked the bureaucratization of the judiciary: the use of rules and procedures to impose an impersonal and regular form of justice. Unlike the authors of the Canons, who used the statement of abstract aspirations to project what they believed to be the reality, the ABA designed the rules to actually effect this purpose.

With the goal of bureaucratization in mind, detachment of the judicial branch-as contrasted with detachment of individual

154. Model Code of Judicial. Conduct (1972) (amended 2007).

155. E.g., Rondal G. Downing, Judicial Ethics and the Political Role of the Courts, 35 Law \&c Contemp. Probs. 94, 105 (1970); Arthur Selwyn Miller, Public Confidence in the Judiciary: Some Notes and Reflections, 35 LAw \& ContEMP. Probs. 69, 87 (1970); J. Harvie Wilkinson III, John P. MacKenzie's The Appearance of Justice, 60 VA. L. REv. 1103, 1103 (1974) (book review).

156. Miller, supra note 155 , at 91.

157. William J. Brennan, Jr., Reason, Passion, and "The Progress of the Law," 10 Cardozo L. Rev. 3, 18 (1988) (citing Max Weber, 2 Economy and Society 983 (1978)). Elaborating on Weber's theory, Justice Brennan observed that "the bureaucratic model of authority ... aspires ultimately to banish passion from government altogether, and establish a state where only reason will reign." Id. 
judges-grew to define judicial independence. This sort of bureaucratic separation became the source of legitimacy for the judiciary. Given the growingly elusive nature of the rule of law, the central way to secure the independence of the judicial branch seemed to be to prevent bias and partisan politics from infiltrating the judiciary. This separation of function replaced the special nature of legal reasoning as the source of legitimacy for the judiciary. The Code, unlike the Canons that came before, licensed some judges and administrators to impose uniformity on others. It recognized and perpetuated a hierarchy and internal order, which manufactured the image of impersonal justice for very different reasons from those advanced in 1924.

The new rules against discourtesy and intemperate conduct were remnants of an older conception of personal judicial independence. They were carried over without much deliberation even though they failed to promote the prevailing concern of branch independence, nor did they comport with the creative new understanding of personal independence expressed by Justices Black and Douglas. What they did do was provide a way for judges and others who staffed state judicial commissions to police the judiciary, enforcing a uniformity of style in keeping with the bureaucratic model. This Part provides background to the drafting of the Code of Judicial Ethics, explains the perceived crises that prompted the bar to make the ethical rules binding, and reviews the competing conceptions of independence. It then analyzes how the Code attempted to address the prevailing concerns and the role that the courtesy rules played in this strategy.

\section{A. Background}

In 1939, Congress established judicial councils for federal courts composed of circuit and district court judges along with members of the bar. The purpose of these bodies was largely administrative. They were designed to give the courts a mechanism to improve efficiency and the administration of justice. ${ }^{158}$

Shortly thereafter, New York and California established judicial discipline commissions to investigate and sanction judges for misconduct. In 1948, New York established a Court on the Judiciary. Twelve years later, California established an agency called the Commission on Judicial Qualifications. Both were authorized to engage

158. An Act to Provide for the Administration of the United States Courts, ch. 501, $\$ \S 306-307,53$ Stat. 1223, 1224-25 (1939); H.R. REP. No. 76-702, at 1-2 (1939). 
in confidential hearings to investigate complaints about judges, and to recommend appropriate action-including censure or removal-to the state supreme court. ${ }^{159}$ By 1970 , twenty-five states had adopted similar procedures to deal with judicial misconduct. ${ }^{160}$

As the 1960s progressed, the public grew more attentive to judicial corruption. ${ }^{161}$ A series of scandals late in the decade precipitated the drafting of the Code as a set of rules meant to be enforceable by judicial commissions, not simply precatory. Ethical scandals surrounded the failure of the nominations of Abe Fortas and Clement Haynsworth to serve as Chief Justice of the Supreme Court. ${ }^{162}$ And more allegations of unethical conduct drove the House minority leader Gerald Ford's effort to impeach Justice William O. Douglas in 1970.163 Meanwhile, in 1966, Senator Joseph D. Tydings of Maryland, Chairman of the Subcommittee on Improvements in the Judicial Machinery, held hearings to investigate problems with the administration of justice. ${ }^{164}$ The product of

159. William T. Braithwaite, Judicial Misconduct and How Four States Deal With It, 35 LAW \& Contemp. Probs. 151, 155 (1970).

160. Id.

161. John H. Holloman III, The Judicial Reform Act: History, Analysis, and Comment, 35 Law \& ConTEMP. Probs. 128, 133-34 (1970) (discussing the increasing public awareness of judicial corruption in the 1960s); see also JOSEPH BORKIN, THE CORRUPT JUDGE 120, 207-08 (1962) (describing prior instances of judicial corruption and proposing a method for dealing with judicial misconduct).

162. In 1968, when Earl Warren announced his retirement as Chief Justice, President Johnson nominated his close friend and adviser, Associate Justice Abe Fortas, to take Warren's place. The confirmation hearings revealed that while serving on the Court, Fortas had regularly attended White House staff meetings, had revealed details of Court deliberations to the President, and had pressured Senators who opposed the Vietnam War to be more compliant. Adding fuel to growing opposition to Fortas's appointment was the revelation that Fortas had been receiving a $\$ 15,000$ salary to teach a summer course at American University. President Johnson ultimately withdrew the nomination when he realized that he lacked the votes to end a filibuster. The following year, Fortas resigned from the Court upon the discovery that he was receiving a yearly stipend of $\$ 20,000$ from Wall Street financier Louis Wolfson, who was under investigation for securities fraud. See Holloman, supra note 161, at 136; LAURA Kalman, Abe Fortas: A Biography (1992). In addition, President Nixon's nomination of Clement Haynsworth for Chief Justice foundered upon allegations that Haynsworth had supported segregation, and as a lower-court judge had rendered decisions that advanced his financial interests. See Stephen L. Wasby \& Joel Grossman, Judge Clement F. Haynsworth, Jr.: A New Perspective on His Nomination to the Supreme Court, 1990 DUKE L. J. 74, 75-77.

163. Ford moved to impeach Justice William O. Douglas based on Douglas's connection with, and supplemental income from, the Albert Parvin Foundation, which allegedly had ties to organized crime. See James F. Simon, IndEPENDENT Journey: The Life of William O. Douglas 392, 398 (1980).

164. Holloman, supra note 161 , at 135. 
these hearings, the proposed Judicial Reform Act, would have created a Commission on Judicial Disabilities and Tenure, composed of five federal judges, to be appointed by the Chief Justice. ${ }^{165}$ If four members of the Commission found that a judge's conduct was inconsistent with the "good behavior" standard, the Commission would recommend removal to the Judicial Conference, a body of federal judges responsible for adopting rules for the administration of the United States Courts. ${ }^{166}$ The bill would have empowered the Judicial Conference to remove the judge subject to discretionary review by the Supreme Court. ${ }^{167}$ By 1970, Tydings' bill had earned the support of the ABA and the Nixon administration, but was defeated by strong opposition from Senator Sam Ervin and others. ${ }^{168}$ In 1969, Bernard Segal, the President of the ABA, appointed a special committee on the standards of judicial conduct to revise the Canons of Judicial Ethics. ${ }^{169}$

In 1970, the Supreme Court itself was confronted with the question of how extensively the judicial councils could regulate in-

165. Sam J. Ervin, Jr., Separation of Powers: Judicial Independence, 35 LAw \& CoNTEMP. Probs. 108, 123 (1970). See generally Comment, The Limitations of Article III on the Proposed Judicial Removal Machinery: S. 1506, 118 U. PA. L. Rev. 1064 (1970).

166. 28 U.S.C. \$ 331 (1948); see also, Todd David Peterson, Congressional Investigations of Federal Judges, 90 IowA L. REv. 1, 29-49 (2004). The Judicial Conference, formerly known as the Conference of Senior Circuit Judges, was founded in 1922. For a full history of the Judicial Conference, see Judith Resnick, Constricting Remedies: The Rehnquist Judiciary, Congress, and Federal Power, 78 IND. L.J. 223, 272-90 (2003).

167. 28 U.S.C. $\$ 331$ (1948). There was a constitutional debate as to whether a federal judge could be removed in any manner short of impeachment. Tydings and other proponents of the bill argued that because Article III, $\S 1$ of the Constitution demanded only that they hold their offices "during good Behaviour," judges could be removed for failing to live up to a higher standard by methods other than impeachment. Holloman, supra note 161 , at 135 .

168. Holloman, supra note 161 , at $142-43$.

169. Chaired by Robert J. Traynor, retired Chief Justice of the Supreme Court of California, the committee consisted of prominent lawyers, judges, and law professors, including United States Supreme Court Justice Potter Stewart, United States Circuit Judge Irving R. Kaufman, and Professor Geoffrey Hazard of Yale Law School. The other members of the committee were Walter P. Armstrong, Jr., a lawyer from Tennessee, E. Dixie Beggs, a lawyer from Florida, Edward T. Gignoux, Chief Judge of the United States District Court of Maine, James K. Groves, Justice of the Supreme Court of Colorado, Ivan Lee Holt, Jr., a Judge in Missouri appellate court, Robert A. Leflar, Professor at the Arkansas Law School, William L. Marbury, a lawyer in Maryland, George $H$. Revelle, a Judge of the appellate court in Washington, Whitney North Seymour, a lawyer in New York, W.O. Shafer, a lawyer in Texas, and Edward L. Wright, a lawyer in Arkansas. The Reporter was E. Wayne Thode, a professor at Utah College of Law. E. WAYNE Thode, RePorter's Notes to Code of Judicial Conduct (1973). 
dividual judges. In 1966, the Judicial Council for the United States Court of Appeals for the Tenth Circuit stripped Judge Stephen Chandler of all his pending cases and prevented assignment of new cases until further review, ${ }^{170}$ though eventually, the Council agreed to return to Chandler his pending cases but to assign no new cases. In response to Chandler's challenge to this decision, Chief Justice Burger, writing for the majority, cryptically dismissed the petition on grounds that Chandler had not "made a case for the extraordinary relief" he sought. ${ }^{171}$ Burger reasoned that Chandler agreed to the order, thereby waiving the right to relief. Had he withheld consent, further proceedings would have been available. ${ }^{172}$ In a dissent joined by Justice Black, Justice Douglas argued that Chandler's consent was irrelevant because the order unconstitutionally interfered with the independence of the judiciary. ${ }^{173}$

\section{B. Reasons for the Code of Judicial Conduct}

The authors and proponents of the Code of Judicial Ethics cited all the recent controversy along with a more generalized distrust of government as among the causes of a growing lack of confidence in the judiciary. ${ }^{174}$ In discussing the need for enforceable judicial ethics rules, Rondal G. Downing, a professor of political science, explained:

The sense of malaise that settled over much of America during the last part of the 1960s appears to be broadening and deepening as we enter the 1970s. Unease continues to be reflected in the attitudes that Americans have toward their nation, its problems and its prospects for the future. These attitudes alone constitute a problem of formidable dimensions reflecting as they do a widespread lack of confidence in virtually every

170. Chandler v. Judicial Council of the Tenth Circuit of the U.S. (Chandler II), 398 U.S. 74, 77-78 (1970). Chandler challenged the first order in the Supreme Court in 1966, but the Supreme Court denied his petition on the ground that the order was interlocutory, pending further proceedings before the council. Chandler v. Judicial Council of the Tenth Circuit of the U.S., 382 U.S. 1003, 1003-04 (1966).

171. Chandler $I I, 398$ U.S. at 89.

172. Id. at 87.

173. See id. at 136-41 (Douglas, J., dissenting).

174. See, e.g., Irving R. Kaufman, Lions or Jackals: The Function of a Code of Judicial Ethics, 35 LAW \& CoNTEMP. Probs. 3, 3-4 (1970) (remarking that the furor over the Fortas controversy had by then turned to substantive proposals for revised canons of judicial ethics); George Edwards, Commentary on Judicial Ethics, 38 FordHAM L. REv. 259, 260-63 (1969); Wilkinson, supra note 155, at 1103; Downing, supra note 155 , at 94 . 
American institution, especially political and governmental institutions. ${ }^{175}$

The judicial branch had escaped the 1960s relatively unscathed for a few years because of the Supreme Court's civil rights record and its position of relative moral authority following Watergate, but the courts were soon caught in the anti-government rhetoric. ${ }^{176}$

The allegations of financial impropriety leveled at Fortas, Haynsworth, and Douglas did more than simply cast a shadow on the particular justices involved; they also exacerbated complaints about a highly politicized Court in a highly politicized time and provided fodder for proponents of the Code. Contemporary commentary lamented that the courts had become so embroiled in the segregation battle that they were seen as a political battleground. ${ }^{177}$ Proponents of a new code of ethics for judges saw the trial of the Chicago Seven, the defendants charged in relation to the protests surrounding the Democratic National Convention in 1968, as evidence of the devolution of justice. ${ }^{178}$ The trial swept courts into the then-diminished repute of all government institutions. ${ }^{179}$ As in the 1920 s, the suspicion of the judiciary was characterized by a sense that courts had become as politicized as the other branches of government. ${ }^{180}$ As Downing argued, courts were drawn into the most politically troubled waters since Brown. ${ }^{181}$

175. Downing, supra note 155, at 94; see also Tom C. Clark, Judicial Self-Regulation-Its Potential, 35 LAw \& CoNTEMP. ProBs. 37, 37 (1970) ("Faith in the Establishment and the personalities that people it has been increasingly on our minds in the last half decade of the sixties. Indeed our young people have hammered home the idea that all is not well with either the Establishment or those who operate it."); Ervin, supra note 165, at 122 ("Beyond doubt during this era of social upheaval, there is a rather extraordinary lack of confidence in many of our governmental institutions, including the judiciary.").

176. Wilkinson, supra note 155 , at 1103.

177. Id. at 1103-04.

178. In that trial, one of the defendants called the presiding judge, Julius Hoffman, a "pig" and a "racist," and the judge, in response, had the defendant bound and gagged in the courtroom. At another point in the trial, two of the defendants arrived dressed in judicial robes and blew kisses to the jury. Downing, supra note 155, at 94-95. Commentators pointed to the trial to illustrate that the courts had lost control and that justice seemed arbitrary and personal rather than abstract and regular. Id.

179. Id. at 95-96.

180. Friedman, supra note 3, at 986. See generally Alexander Bickel, The Supreme Court and the Idea of Progress (1970).

181. Downing, supra note 155 , at 97 . For example, courts were determining the degree of permissible segregation and of discrimination in public education, transportation, and housing; they were deciding the degree to which protests and demonstrations-particularly protests against the Vietnam War-were to enjoy 
The growing disillusionment with the judiciary was accompanied by changing ideas about the role of the law. Recognizing that judges make the law, jurists acknowledged that there was no natural divide between the political and judicial branches. ${ }^{182}$ They used the courtesy rules to erect an artificial barrier in its place. As J. Harvie Wilkinson III, then a professor at the University of Virginia School of Law, noted, "Though we have come to expect judges to bring to the bench decided views on constitutional policy, we have also come to insist that they be clear of questionable financial conflicts or other trace[s] of ethical compromise."183 In some ways, the courtesy rules were seen as an antidote to the diminished public confidence in the courts' legitimacy and the rising perception that they were highly politicized: "It may well be the ethics of the judge that assure his legitimacy. More and more, legislators and judge are being drawn into the same territory." 184 The Code's ethical proscriptions served to insulate the judiciary from the political branches; no longer to project an image of the separate branch functions that the authors of the Canons believed existed by nature of legal reasoning.

\section{Ideas of Independence}

The crisis of public confidence in the judiciary spawned a conversation about independence. In light of changing jurisprudential views, however, independence shifted meanings. Most scholars in the late 1960s and 70s understood judicial independence in terms of detachment from the political branches, rather than personal independence. The question that plagued contemporaries was, if the unique nature of legal reasoning cannot naturally and logically separate the judiciary from the legislature and executive, then what does? Most jurists assumed that controls implemented by a central bureaucracy would create an artificial divide, which would serve to ensure a new kind of independence. They thought that only by emptying out that which made him human, by putting aside emotion or politics or preconceptions, could a judge correctly ascertain the true and just law.

In the late $1960 \mathrm{~s}$, the concept of branch independence dominated, and most jurists simply ignored the idea of personal inde-

constitutional protection. In addition, courts were being asked such controversial questions as how much protection should be given to pornography and obscenity and how extensively to interpret the separation between church and state. $I d$.

182. See Horwirz, supra note 2, at 247-68.

183. Wilkinson, supra note 155 , at 1103 .

184. Id. 
pendence. The independence of individual judges, as opposed to the judicial branch, assumed a secondary status, although a few iconoclastic judges, including Justices Black and Douglas, reinvented the meaning of personal independence in light of jurisprudential changes, arguing that judges must be free to express (rather than repress) their own political, ideological, jurisprudential, or emotional views. ${ }^{185}$ This view of personal judicial independence, however, was in tension with branch independence and did not significantly shape the drafting of the Judicial Code.

Charles D. Breitel, then-justice of the Appellate Division of the Supreme Court of New York, explained that it is a myth that the three branches of government are separated based on hard-line division of powers or functions. But he wrote that there is "a desirable division of power to prevent domination by any one branch or organ of government."186

Although concerned about the appearance of impartiality, commentators were no longer preoccupied with each judge's appearing neutral and machine-like. Instead, they wanted the entire branch to seem uniform and apolitical. ${ }^{187}$ The fear was no longer that judges might allow their own preconceptions and idiosyncrasies to seep in, but rather that the population would perceive the entire branch as an arm of the party in power. ${ }^{188}$ As Judge Irving $R$. Kaufman, a member of the Special Committee on Standards of Judicial Conduct of the ABA, explained: "[I]mpartiality and insulation from pressures by the political branches are essential attributes of judicial power."189

Virtually no one still maintained the idea that judges ought to suppress their individual personalities to ascertain the correct meaning of the law. Some jurists did, however, promote a new kind of personal independence for judges. Judge Kaufman explained:

There are times when we need men who can feel and understand what goes on in the world about them; we shall not find such men in a gray "bureaucracy" divorced from all outside activities and interests. And there are times, I might add, when

185. See supra notes 171-74 and accompanying text; infra notes 192-95 and accompanying text.

186. Charles D. Breitel, The Lawmakers, 65 Colum. L. Rev. 749, 750 (1965). The following year Breitel was appointed to the New York Court of Appeals, where he served as Chief Judge from 1973 to 1979.

187. See, e.g., Dean Acheson, Removing the Shadow Cast on the Courts, 55 A.B.A. J. 919, 920 (1969); Breitel, supra note 186.

188. Braithwaite, supra note 159 , at 153.

189. Kaufman, supra note 17, at 694 . 
we need men who are not afraid to roar should the occasion demand it. ${ }^{190}$

Furthermore, the more oversight and regulation of judges, the greater the danger that each judge will lose his own independent judgment, his ability to draw on his personality, intuition, and emotions to determine the just outcome of a case. ${ }^{191}$ Justice Douglas in his dissent in the Chandler opinion articulated this version of personal independence most passionately. He elaborated his understanding of judicial independence, which was quite distinct from and in some way opposed to the dominant view of branch independence:

An independent judiciary is one of this Nation's outstanding characteristics. Once a federal judge is confirmed by the Senate and takes his oath, he is independent of every other judge. He commonly works with other federal judges who are likewise sovereign. But neither one alone nor any number banded together can act as censor and place sanctions on him. ${ }^{192}$

He explained the mood on the other side: "[S]ome federal judges [are] opposed to this view and they are active in attempting to make all federal judges walk in some uniform step." 193 According to Justice Douglas, the danger of eroding this sort of personal independence was dire because it allowed one set of judges to impose their own personal views on others:

And whose "public interest" would control? Judges who have not been educated to the needs of ecology and of conservation? Judges who still have a "plantation" state of mind and relegate many minorities to second-class citizenship? Judges who have a narrow view of freedom of expression or a broad view of due process? Public issues deal with a vast contrariety of views; and judges, like other people are to be found in all parts of the spectrum. How under the Constitution can one judge's lips be sealed because of the predestined view of other judges? ${ }^{194}$

190. Kaufman, supra note 174 , at 8 .

191. See, e.g., Beverly Blair Cook, Perceptions of the Independent Trial Judge Role in the Seventh Circuit, 6 LAw \& Soc'y REv. 615 (1972) (examining contrasting perspectives on the increase in bureaucratic oversight of the federal judiciary during the twentieth century).

192. Chandler v. Judicial Council of the Tenth Circuit of the U.S. (Chandler II), 398 U.S. 74, 136 (1970) (Douglas, J., dissenting).

193. Id. at 137.

194. Id. at $139-40$. 
This multiplicity and diversity of judicial views, the heritage of Cardozo's experiment in judicial styles, was, according to Justice Douglas, the key to legitimacy for the courts. He elaborated, "Some of the idiosyncrasies may be displeasing to those who walk in more measured, conservative steps. But those idiosyncrasies can be of no possible constitutional concern to other federal judges." ${ }^{195}$ Despite the arguments in support of this view, ${ }^{196}$ they were relatively ineffectual at preventing the increasing bureaucratization of the judiciary, and the Code drafters ultimately gave this emphasis on personal independence no weight in their final product. As Senator Sam J. Ervin explained, "Judicial independence can just as easily be eroded by powerful hierarchies within the judiciary itself as by outside pressures from the legislative and executive branches of the government."197

At least some members of the committee were, however, concerned about the cost that the Code might have for personal independence, as they now defined it. They were concerned about chilling productive judicial styles and argued for a careful implementation of the Code. Judge Kaufman, for example, sought to craft the rules so as to avoid interfering with personal independence. He felt the rules should not comprise "wholesale prohibitions," but rather guidelines, trusting the general discretion of judges. ${ }^{198} \mathrm{He}$ also believed it important to allow judges to engage in extra-judicial activities to prevent "judicial myopia in an age that incessantly demands more independence and more understanding to solve the increasingly complex and sensitive issues our society leaves to be settled by litigation."199 He worried that additional controls on the judiciary would invite dissatisfied litigants to harass judges and deter them from rendering any potentially controversial decision, "irreparably chilling fearless and impartial adjudication."200

195. Id. at $140-41$.

196. George Edwards, Judge of the United States Court of Appeals for the Sixth Circuit, echoed Kaufman's call: "The American judiciary is not and should not become a grey bureaucracy completely remote from the life and the problems of the nation." Edwards, supra note 174, at 275. He continued: "The family, the home, the neighborhood, the school, job, marriage, military experience, travel, friends, avocations-all inevitably become a part of the judge, just as they do of other men. No judge can ever really disassociate himself from his origin, history, and his present life. Nor should he try." Id. at 278.

197. Ervin, supra note 165, at 125.

198. See Kaufman, supra note 174, at 6.

199. Id. at 7.

200. Kaufman, supra note 17 , at 700 . 
In 1969, George Edwards, a judge on the United States Court of Appeals for the Sixth Circuit, echoed these concerns. He argued against the recent furor following the Fortas scandal, suggesting that it would be a grave error to ask judges to avoid all criticism: "Such a standard would certainly eliminate as judicial heroes such giants of our legal history as Brandeis, Holmes, Frankfurter and Warren."201 Thus, he argued that the Code should not require a judge to divorce himself from the world. The robes cannot, and should not, force a judge to rid himself of everything that makes him human. ${ }^{202}$

\section{Bureaucratization Through the Courtesy Rules}

When the ABA convened the Special Committee on Standards of Judicial Conduct to help codify the rules of judicial conduct, it was concerned with how to manufacture judicial uniformity and branch independence without faith in law as something naturally distinct from politics. The goal of the new Code was to create bureaucratic divisions between the judiciary and the political branches of government, preventing bias in proceedings, and promoting the efficient administration of justice. To that end, the authors focused primarily on extra-judicial and quasi-judicial activities, compensation for such activities, financial and business dealings, and disqualification for personal interest. ${ }^{203}$

As Dean Acheson argued, branch independence required judges to disassociate from all civic and political activity: "The most important extra-judicial assignments distract from judicial tasks, and lesser ones may bring involvement in controversies detracting from judicial impartiality and aloofness."204 The term "aloofness" implies an intentional separation from the affairs of the world. Advocating a kind of bureaucratic wall between the judiciary and the political branches, Acheson criticized the Supreme Court justices who crossed the divide. He cited Chief Justice Warren's role presiding over the commission to investigate the assassination of John $F$.

201. Edwards, supra note 174, at 273.

202. See id.

203. See Preliminary Statement Accompanying the Interim Report of the Special Committee on Standards of Judicial Conduct (June 1970), in Collec tion of Miscellaneous Documents Collected from the American Bar Association Speclal Committee on Standards of Judiclal Conduct, 1970-72 (American Bar Association Archive Pubs.); General Reactions to the INTERIm RePort (Sept. 22, 1970), in Collection of Miscellaneous Documents Collected from the American Bar Association Special Committee on Standards of Judicial ConDUCT, 1970-72, supra; Kaufman, supra note 174, at 4-7.

204. Acheson, supra note 187 , at 920 . 
Kennedy, Justice Robert Jackson's service as chief American prosecutor at the Nuremburg trials, and Justice Goldberg's resignation to serve as representative to the United Nations as evidence of this insidious blurring of the line between the political extracurriculars and the judicial function. ${ }^{205}$

Judicial courtesy was one approach within the new rules to build bureaucratic constraints into the judiciary. Those who engaged in the limited public debate around the courtesy rules viewed judicial demeanor as a way of projecting a judiciary free from partisan political agendas, a court free from clear bias. ${ }^{206}$ An article in Fortune Magazine put it this way:

Today, traveling through a time of exceptional stress, the U.S. needs more than ever to be escorted by effective justice and by serene, civilized courts. Even in the best of times, American courts have suffered too much from politics, corruption, and judicial incompetence. The legal process seemed too often to be a weapon used by the dominant forces in society against the poor and the minorities, who needed protection the most. ${ }^{207}$

Insofar as there was any deliberate concern for judicial discourtesy, it arose from a perceived need to portray the courts as a bureaucracy that could serve as a neutral arbiter in the cultural war. ${ }^{208}$ The problem with Judge Hoffman's response in the trial of the Chicago Seven was not his behavior in itself, but rather his apparent bias against the defendants. ${ }^{209}$

However, the courtesy rules created the danger of deterring alternate judicial styles and encouraging a bureaucratic style of judging. In this way, the courtesy rules undermined the new understanding of personal (as distinct from institutional) independence in which judges would be free to draw on their personality and emotions to craft the proper solution, which was championed by a few notable observers at the time.

\section{IV. \\ REGULATING JUDICIAL COURTESY}

Beginning in the 1970s, states established commissions to regulate judges and adopted the new Code of Judicial Conduct as the

205. See id.

206. Braithwaite, supra note 159 , at 152.

207. Jeremy Main, Only Radical Reform Can Save the Courts, ForTune, Aug. 1970 , at 112 .

208. Id.

209. See Jon Wiener, Conspiracy in the Streets: The Extraordinary Trial. of THe Chicago Eıght 27 (2006). 
governing standards. With the expansion of judicial self-regulation, the ABA's judicial ethics code became more than a statement of professional aspiration. State courts' interpretations of the courtesy rules along with commissions' enforcement of the rules offer further insight into evolving views of judicial independence. The enforcement of norms governing judges' courtroom demeanor marks a sea change from the early days when judges' personal independence to administer judicial proceedings as they saw fit was taken for granted and concerns about protecting judicial independence centered on judges' decision-making role and on judicial outcomes.

Judges have expressed concern that an overly broad interpretation along with excessive enforcement of the courtesy rules may encroach on individual judges' independence from the judiciary as an institution by chilling their ability to address legitimate ends through individual styles and through the expression of individual personality. ${ }^{210}$ Nonetheless, courts have allowed regulatory authorities to punish judges if they appear to overstep the bounds of courtesy even while serving legitimate ends. ${ }^{211}$ Thus, the judiciary as an institution has bartered the independence of individual judges in order to preserve its branch independence, using a robust idea of courtesy to perpetuate the myth that individual personality and emotion play no role in the judicial function. Strict enforcement of courtesy rules, largely for the sake of appearance, unduly interferes with judges' latitude to administer judicial proceedings, and more cautious enforcement should be employed to preserve the ability of judges to draw on individual personality, intuition, and emotions, and generally to adopt an activist or experimental approach to the conduct of the courtroom.

\section{A. Regulatory Background of the Courtesy Rules}

The establishment of judicial conduct commissions in the 1970 s shifted the focus of judicial regulation generally, ${ }^{212}$ and of the regulation of discourtesy in particular. Until then, courts had

210. See infra Part IV.B.1.

211. See infra Part IV.B.2.

212. According to a bar association report tracing the history of judicial discipline in New York, in the first twenty years after the state adopted a Commission on Judicial Conduct, the Commission removed 110 judges and publicly disciplined more than 400 others, whereas the state legislature had not removed a judge in more than 120 years. Task Force on Judicial Selection \& Court Merger, Ass'n of the Bar of the City of N.Y., Judicial Accountability and Judicial Independence, 51 Rec. 629, 630 (1996). 
limited occasion to reflect on questions of judicial personality in their opinions. The judicial Canons were originally aspirational, not enforceable, and therefore were rarely the subject of judicial decisions. Only extreme cases of judicial misconduct subjected judges to legislative impeachment, criminal indictment, or other extreme sanctions that might be available. Impatience and discourtesy in running a courtroom obviously would not qualify, ${ }^{213}$ but at best were regulated informally through the influence of friends and colleagues or public criticism in the media. ${ }^{214}$

Before the advent of judicial conduct commissions, appellate courts reviewing trial court proceedings did have occasions to determine whether a judge's bullying or harassing conduct deprived a party of a fair trial or necessitated the judge's recusal. ${ }^{215}$ But in this context, the question before courts was not whether the judge engaged in misconduct calling for some measure of moral opprobrium, much less whether the judge's conduct suggested that he was temperamentally unsuited to continue to serve. Judicial excess necessitating an appellate remedy could just as easily be characterized as trial error or misjudgment as it could misconduct, and courts generally had no need to draw the distinction. The focus was on appellate review as a mechanism for regulating proceedings, not for regulating lower court judges per se, and therefore an opinion critical of a judge was not necessarily the functional equivalent of a reprimand.

Consequently, high-minded judicial rhetoric about judges' demeanor had little practical significance; the aspirational statements standing alone did not compromise individual judges' independence. Judicial impatience was the stuff of lore, not law, and the trial lawyer's expected response was not to file a grievance but to

213. See generally Martin H. Redish, Judicial Discipline, Judicial Independence, and the Constitution: A Textual and Structural Analysis, 72 S. CAL. L. REv. 673, 682-96 (1999) (analyzing scope of congressional authority to impeach federal judges).

214. See generally Sambhav N. Sankar, Comment, Disciplining the Professional Judge, 88 CAL. L. REv. 1233, 1254-55 (2000) (describing informal discipline of judges).

215. Compare, e.g., W. Coal \& Mining Co. v. Kranc, 100 S.W.2d 676, 677 (Ark. 1937) (cautioning against impatient remarks and comments that might prejudice a party or improperly sway the jury), and Pickerell v. Griffith, 29 N.W.2d 588, 595, 597 (Iowa 1947) (reversing judgment in part because trial judge improperly rebuked counsel), with Loreno v. Ross, 133 So. 251, 253 (Ala. 1931) (finding that trial court properly instructed counsel to "keep quiet" to protect opposing party's right of cross-examination), and Ryan v. Crookston, 30 N.W.2d 351, 352 (Minn. 1947) (holding that most of trial judge's challenged remarks were justified to ensure an orderly process). 
grow a thicker skin.216 Evolving and competing theories of judging underlying discussions of courtesy remained, but were not implemented or tested, because the injunction against judicial discourtesy had no legal bite.

The establishment of judicial conduct commissions changed that by requiring courts to determine when procedural error constituted misconduct. ${ }^{217}$ The unenforceable judicial ideal that judges should be patient, dignified and courteous became an enforceable standard of conduct. ${ }^{218}$ Any judge who responded impatiently or discourteously to parties or their lawyers could be potentially sanctioned by suspension or removal from the bench or by a lesser punishment such as public censure that would affect the judge's reputation and ability to win reappointment or reelection. ${ }^{219}$

Given the breadth of the judicial standard-cum-rule, the ABA or state courts might have been expected to narrow it when the judicial Canons were revised. However, state judiciaries almost entirely relied on the ABA models, and, as noted, the ABA drafters gave no serious thought to the courtesy rules. ${ }^{220}$

216. See, e.g., McBryde v. Comm. to Review Circuit Counsel Conduct and Disability Orders of the Judicial Conference of the U.S, 264 F.3d 52, 84 (D.C. Cir. 2001) (Tatel, J., dissenting) (noting that "reasonably resilient and thick-skinned lawyers [may have the ability] to present their cases effectively" despite a judge's harsh management style).

217. Some courts attempted to draw a line between mere judicial error, which does not subject a judge to discipline, and legal error which "clearly and convincingly reflects bad faith ..., bias . .., abuse of authority ..., disregard for fundamental rights ..., intentional disregard of the law ..., or any purpose other than the faithful discharge of judicial duty." Oberholzer v. Comm'n on Judicial Performance, 975 P.2d 663, 680 (Cal. 1999) (citations omitted); see also Gerald Stern, Judicial Error That Is Subject to Discipline in New York, 32 Hofstra L. REv. 1547, 1562 (2004) (asserting that "[d] isciplining judges for errors of law is controversial," but nevertheless advocating sanctions for "flagrant" or "egregious" legal error).

218. See, e.g., Gregory C. O'Brien, Jr., Speech May Be Free and Talk Cheap, but Judges Can Pay a Heavy Price for Unguarded Expression, 28 LoY. L.A. L. Rev. 815, 821-23 (1995) (describing cases where judges were sanctioned for abusive conduct).

219. The judge is potentially subject to discipline in the lawyer disciplinary process as well.

220. The most recent round of revisions to the judicial canons involved disagreement about whether to delete the requirement that judges avoid the "appearance of impropriety." See, e.g., Ronald D. Rotunda, Judicial Ethics, the Appearance of Impropriety, and the Proposed New ABA Judicial Code, 34 HofsTrA L. REv. 1337, 1340 (2006) (criticizing the "appearance of impropriety" standard as unduly vague). But no attention was paid to the courtesy rule, which was slightly expanded. As newly amended and renumbered, the courtesy rule, Rule 2.8(b) of the Model Code of Judicial Conduct, provides: "A judge shall be patient, dignified and courteous to litigants, jurors, witnesses, lawyers, court staff, court officials, and others with whom 
The question then became how to interpret and enforce the rules. Few would quarrel with applying the rules to certain judicial conduct, such as when judges' unprovoked and purely gratuitous rudeness creates a judicial atmosphere in which participants are intimidated from making the full presentation necessary to a fair decision, or when discourtesy is symptomatic of impermissible bias. But it would be unrealistic to expect every judge who displays discourtesy to be disciplined under the courtesy rule, notwithstanding its broad and unqualified language. ${ }^{221}$ Even judges with the most impressive self-control are prone to impatience in response to the pressures of a demanding docket, an obstreperous lawyer, or circumstances outside court, and some can be short-tempered but still be regarded as fair and impartial.222 The question for judicial commissions is whether self-expression that crosses the line should be regarded as morally blameworthy conduct worthy of punishment, rather than as judicial error like other procedural error.

Whether discourteous acts and statements will be branded as judicial misconduct, labeled as merely an error or misjudgment, or regarded as a legitimate if debatable expression of the judicial role reflects how judicial institutions regard particular conceptions of judicial independence. On the one hand, aggressive applications of the rule and literal judicial interpretations preserving the possibility that the rule may be invoked for any expression of impatience, breach of dignity, or discourtesy promote the image of judicial detachment in order to preserve branch independence, but do so at the risk of chilling legitimate behavior. Limitations on the use of the rule, in turn, privilege individual independence by giving freer play to judicial management styles and judicial philosophies that involve bringing one's full personality to the task of judging, but do so at risk to public respect for the legitimacy of the judiciary as an

the judge deals in an official capacity ...." Model. Code of Judicial Conduct $R$. 2.8(b) (2007). The earlier provision, Canon $3 B(4)$, which is the basis of most current state judicial codes, made no express reference to court staff and officials. Model Code of Judicial Conduct Canon 3B(4) (1990).

221. See Norman L. Greene, A Perspective on "Temper in the Court: A Forum on Judicial Civility, " 23 FORDHAM URB. L.J. 709, 712, 716-17 (1996) (maintaining that judges' “blatant rudeness, nastiness, and arrogance ... are well known to people who are frequently in the [New York] courts," and identifying alternative ways of seeking to remedy it).

222. See, e.g., Jan Hoffman, The Transformation of a Judge; A 35-year Journey Starts on Left and Goes Right, N.Y. Times, Feb. 4, 1996, $\S 1$, at 35 (discussing trial court judge, Harold Rothwax, known as the Prince of Darkness in part for his harsh courtroom demeanor, and quoting Manhattan district attorney: "He's a tough judge and a no-nonsense guy, but that doesn't make him pro-prosecutorial. He calls the issues as he sees them."). 
institution. Some judicial discussions of courtesy recognize this tension, but others fail to take it into account. ${ }^{223}$

\section{B. Interpreting the Courtesy Rules}

In the context of interpreting and applying the rules governing judicial courtesy, authorities have considered the relationship between expectations of judicial courtesy and conceptions of judicial independence. Conceptions of judicial independence, and particularly of individual judges' independence from judicial institutions, implicitly underlie all discussions about the expectations of courtesy. In some cases, these considerations have been brought expressly to the surface. A minority of judges have urged interpreting courtesy rules narrowly, reflecting respect for the values of personal independence and individual judicial style. Others, however, have endorsed broad interpretations that reinforce the image of impersonal judging, thereby privileging institutional independence over the independence of individual judges.

1. Interpretations recognizing the relevance of judicial personality

Given the considerations of judicial independence underlying approaches to judicial courtesy, one might expect courts to read the rules conservatively to incorporate implicit limitations. A few courts and judges have done so by limiting the rules' reach to judges' expressions of impatience or discourtesy that are, in some respect, particularly extreme or harmful. This approach is exemplified by In re Hocking where the Michigan Supreme Court stated that "every angry retort or act of discourtesy during the course of a proceeding does not amount to judicial misconduct. ... [A] judge is only subject to discipline when the comment amounts to "conduct that is clearly prejudicial to the administration of justice.' "224 Authorities have offered various formulations for narrowing the circumstances in which discourtesy subjects a judge to sanction. Some focus on the flagrancy or obviousness of the misconduct ${ }^{225}$ or its harmfulness.226 Some decisions, while not explicitly limiting the courtesy rules' reach, justify the imposition of sanctions by under-

223. See infra Part IV.B.

224. 546 N.W.2d 234, 241-42 (Mich. 1996) (citing MıCH. CT. R. 9.205(E)).

225. See McBryde v. Comm. to Review Circuit Counsel Conduct and Disability Orders of the Judicial Conference of the U.S., 264 F.3d 52, 77 (D.C. Cir. 2001) (Tatel, J., dissenting).

226. See Hocking, 546 N.W.2d at 241-42. 
scoring the extent to which discourtesy expresses bias or undermines the fairness of the process. ${ }^{227}$

Limiting interpretations of judicial standards regulating judges' intemperance might reflect any of several considerations. Chief among these would be a rejection of the idea that judges must project a sober and emotionally detached demeanor in order to convince the public of their impartiality. The leading opinion making allowances for judges' emotions and ordinary human limitations is that of Justice Scalia for the Court in Liteky v. United States. 228 The opinion underscored the need for the law to account for human frailties that do not undermine judges' ability to make decisions fairly and to afford a fair process:

[J] udicial remarks during the course of a trial that are critical or disapproving of, or even hostile to, counsel, the parties, or their cases, ordinarily do not support a bias or partiality challenge. They may do so if they reveal an opinion that derives from an extrajudicial source; and they will do so if they reveal such a high degree of favoritism or antagonism as to make fair judgment impossible. . . . Not establishing bias or partiality, however, are expressions of impatience, dissatisfaction, annoyance, and even anger, that are within the bounds of what imperfect men and women, even after having been confirmed as federal judges, sometimes display. A judge's ordinary efforts at courtroom administration-even a stern and short-tempered judge's ordinary efforts at courtroom administration-remain immune. ${ }^{229}$

227. See, e.g., Dodds v. Comm'n on Judicial Performance, 906 P.2d 1260, 1270 (Cal. 1995) (emphasizing that the judge's rudeness had the effect of denying a party a fair hearing); Sardino v. State Comm'n on Judicial Conduct, 448 N.E.2d 83, 85 (N.Y. 1983) (explaining that the judge's "statements could only create the impression in the mind of the public that he was predisposed against those defendants who appeared before him if not defendants generally").

228. 510 U.S. 540 (1994). The issue was whether a federal district judge had wrongly failed to recuse himself in a criminal case for bias based on 28 U.S.C. $\S 455$ (a), which requires a federal judge to "disqualify himself in any proceeding in which his impartiality might reasonably be questioned." The Court rejected the allegation that "the judge had displayed 'impatience, disregard for the defense and animosity' toward" the defendant, especially by "interrupt[ing] the closing argument of" a co-defendant and "instructing him to cease the introduction of new facts, and to restrict himself to discussion of evidence already presented." Id. at $542-43,556$. The Court's philosophical approach to judicial courtesy would be no less applicable, however, in the context of deciding whether to discipline a judge for misconduct.

229. Id. at 555-56 (emphasis added); see also id. at 550-51 ("The judge who presides at a trial may, upon completion of the evidence, be exceedingly ill disposed towards the defendant, who has been shown to be a thoroughly reprehensible person."). 
Such an approach to courtesy rules would also accommodate the reality of judicial settings. Conduct that might fairly be characterized as discourteous in the abstract can be reasonable in the context of proceedings in which a judge is provoked or is otherwise seeking to maintain order. ${ }^{230}$ Further, a judge's occasional rudeness or discourtesy may be a reaction to the generally stressful conditions in which some judges operate. ${ }^{231}$ Decisions interpreting the courtesy rules narrowly in light of the reality of judges' humanity are not necessarily meant to encourage judges to bring their emotions to their work. 232 But such decisions recognize that the judge's personality, including expressions of temper or impatience, is an important asset in managing the courtroom. Thus, the majority in Hocking cautioned that " $[\mathrm{t}] \mathrm{o}$ hold that a trial judge may not express strong displeasure or even anger, would ignore the reality that the potential for such reactions induces a level of civility in the process, without which the system literally could not function."233

230. See, e.g., Hocking, 546 N.W.2d at 241. After having previously argued at length in favor of a significant sentence, the prosecutor interrupted the judge as he was announcing and justifying a lesser sentence, leading the judge to lose his temper and respond acrimoniously. See id. The judge directed the prosecutor not to interrupt him and to sit down, stating that he was going to fashion the sentence and make comments whether she liked it or not, and challenging her to appeal if she did not like what he said. Id. The Michigan Supreme Court rejected the state commission's finding that the judge was "impermissibly rude" in dealing with the prosecutor in a sentencing hearing. See id. at 236-38. It found the sentencing judge's response to the prosecutor's provocation to be "overly strong" but "also understandable" in light of the prosecutor's breach of courtroom etiquette. Id. at 242.

231. For example, although the Hocking court sustained a different charge arising out of a custody proceeding in which the judge responded harshly to a lawyer's repeated interruptions, a dissenting judge disagreed, maintaining:

Ideally, a judge should not instigate or engage in confrontational behavior or react to such behavior-no matter how provoked. Yet, every attorney who regularly appears before the judges of our state, judges who are forced to operate with limited resources and under great pressure from the docket, will immediately recognize that outbursts like Judge Hocking's are far from infrequent. Most judges wrestle with their self-control, and all hear motions they are predisposed against and antagonistic toward. I join the majority in wishing we could populate our courtrooms with judges devoid of temper and full of angelic patience. But if such perfect creatures exist, their planetary origin is truly unknown.

Id. at 247 (Cavanagh, J., concurring in part and dissenting in part).

232. For example, the dissenting judge in Hocking held that "we do the judiciary a disservice when we condemn human failings as judicial misconduct," but adhered to the ideal that "[j]udges should struggle to maintain their temperament and view the cases before them unobscured by passion." Id. at 247.

233. Id. at 245 (majority opinion). 
Limiting interpretations might reflect at least two additional premises. The first is the need, particularly given the limitations and complexities of extemporaneous verbal expression, to permit individual judges freedom of expression. For example, the Second Circuit's judicial council recently did so in rejecting allegations that a district judge, among other things, engaged in abusive speech. ${ }^{234}$ The court emphasized "that in the heat and tension of court proceedings, ambiguities can easily occur."235 Further, it expressed no doubt about the propriety of the judge's passion-in this case, the trial judge's "growing exasperation"236 - that made clear, measured judicial expression especially difficult.

Second, limiting interpretations may reflect respect for individual judging styles and philosophies. This was expressed most explicitly by Circuit Judge Tatel in a dissenting opinion arising out of the discipline of District Judge John McBryde. ${ }^{237}$ Judge Tatel main-

234. See In re Charges of Judicial Misconduct, 465 F.3d 532, 541-47 (2d Cir. 2006). Federal courts do not enforce the judicial canons but may sanction a federal judge for engaging "in conduct prejudicial to the effective and expeditious administration of the business of the courts." 28 U.S.C. $\$ 372(c)(1)(2000)$. In this case, the disciplinary charge arose out of a capital case in which the defense lawyer, following his client's instructions, refused to challenge the defendant's impending execution. See Charges of Judicial Misconduct, 465 F.3d at 542-43. The judge strongly took issue with the lawyer's conduct in light of doubts raised by other witnesses about the defendant's competence, and the judge warned the lawyer that he risked discipline-threatening, "I'll have your law license" -if it turned out, contrary to the lawyer's belief, that the defendant was incompetent. Id. at 544 . Although the trial judge, in hindsight, acknowledged that he spoke too vehemently "under the stress of the circumstances," $i d$. at 545, and apologized for his choice of words, id. at 546, the circuit's judicial council, adopting the report and recommendations of a three-judge special committee, agreed that he had not engaged in misconduct. Id. at 547. The report recognized that the judge's remark was ambiguous-it could be understood either as an improper threat to misuse his influence to cause the lawyer's license to be revoked or as a permissible threat to refer the lawyer to the disciplinary authorities for an independent determination. Id. at 546.

235. Charges of Judicial Misconduct, 465 F.3d at 547; see also In re Lichtenstein, 685 P.2d 204, 209 (Colo. 1984) (rejecting judicial commission's recommendation to sanction sentencing judge and observing that "[a]lthough the sentencing comments contain some phraseology which, read in isolation, might have offended the sensibilities of others, ... . the choice of words was no more than an awkwardly executed effort" to describe facts justifying the sentence); Hocking, 546 N.W.2d at 240 (observing that "every graceless, distasteful, or bungled attempt to communicate the reason for a judge's decision cannot serve as the basis for judicial discipline").

236. Charges of Judicial Misconduct, 465 F.3d at 546.

237. McBryde v. Comm. to Review Circuit Counsel Conduct and Disability Orders of the Judicial Conference of the U.S, 264 F.3d 52, 76-80 (D.C. Cir. 2001). Judge McBryde was suspended from the bench and reprimanded for a pattern of 
tained "that the principle of judicial independence permits sanctions to be imposed only for conduct that is clearly abusive or clearly prejudicial to the adversarial process," mote[ ] judicial individualism," judicial independence requires some "protection against . . . interference by fellow judges" as well as from other government branches, particularly in the "decisional function." "239 This requires "not only judges' freedom to reach their own conclusions about questions of fact and law, but also a margin of discretion to manage and control the adversarial process within their courtrooms." 240 While acknowledging that federal judicial councils should have power to sanction judges who abuse their trial management authority, he identified several reasons why this power should be used only where judicial conduct was clearly abusive or clearly prejudicial. These reasons include the fact that there are many "appropriate courtroom management techniques"; that appellate judges on judicial councils may lack experience dealing with overly aggressive lawyers and may therefore punish legitimate courtroom management; that unfair or even vindictive colleagues may use judicial discipline "to sanction unpopular judges engaged in appropriate behavior"; and that "judicial discipline, like civil liability for judicial acts, can chill the proper exercise of judicial discretion."241

\section{Interpretations subordinating judicial personality and privileging branch independence}

For the most part, courts and disciplinary bodies purport to take the courtesy rules literally, meaning that a single act of impa-

abusive behavior toward parties, lawyers, and fellow judges, and later challenged the sanction on constitutional and other grounds. A majority of the D.C. Circuit panel rejected the challenge, principally for jurisdictional reasons, but Judge Tatel dissented and, in the process, addressed the merits of Judge McBryde's claims, including his claim that the Judicial Council "unconstitutionally interfered with his judicial independence by punishing him because it disagrees with his judicial philosophy and acts." Id. at 76 (Tatel, J., dissenting).

238. Id. at 77 (Tatel, J., dissenting).

239. Id. (quoting N. Pipeline Constr. Co. v. Marathon Pipe Line Co., 458 U.S. 50, 59 n.10 (1982), and Chandler v. Judicial Council of the Tenth Circuit of the U.S. (Chandler II), 398 U.S. 74, 84 (1970)).

240. Id. at 78.

241. Id. at 80; see also In re Stevens, 645 P.2d 99, 100 (Cal. 1982) (Mosk, J., dissenting); In re Ross, 428 A.2d 858, 866 (Me. 1981). Judge Tatel agreed that even under this standard, some of Judge McBryde's conduct was "so extreme and clearly abusive" as to warrant discipline, but found that most of the conduct on which Judge McBryde's sanctions were premised was either clearly or potentially appropriate. McBryde, 264 F.3d at 81-85 (Tatel, J., dissenting). 
tience will subject a judge to punishment, limited only by the enforcement authorities' discretion whether to initiate proceedings. Against the background of the opinions of Justice Scalia, Judge Tatel, and others implicitly raising concerns that taking expectations of courtesy too literally will encroach on judicial independence, these opinions can be understood as an adoption of the bureaucratic conception of judicial independence and a rejection of the modern individualistic conception.

This predominant literalism is exemplified by the New York State Judicial Conduct Commission's pronouncement that "[e]ven a single instance of intemperate language may be the basis for a finding of misconduct."242 Even when opinions contain some potentially qualifying language or references to the harms caused by incivility, most make no serious effort at line-drawing, viewing discourtesy as a sufficient evil in itself to be regarded as misconduct. In some cases, courts expressly reject considerations identified by those who advocate narrower application of courtesy rules. ${ }^{243}$ In other cases, they do so implicitly. ${ }^{244}$ For the most part, however, courts and judicial commissions make no reference to considerations that counsel against taking courtesy rules literally and, in particular, avoid discussing the concern that regulating judicial courtesy raises profound questions about the judicial role and function. ${ }^{245}$

242. In re Hannigan, N.Y. State Comm'n on Judicial Conduct, 1997 WL 809945 (Dec. 17, 1997) (sanctioning a judge who called an accused "garbage" and "trash," derogated her defense, and attempted to badger her to plead guilty). The opinion cited, by way of illustration, an earlier disciplinary opinion, In re Going, N.Y. State Comm'n on Judicial Conduct, 1997 WL 433228 (July 18, 1997), which is discussed infra at text accompanying notes 254-63.

243. See, e.g., In re Brown, 691 N.E.2d 573, 577 (Mass. 1998) (expressly rejecting the relevance of Justice Scalia's observations in Liteky and concluding that bias and prejudice are unnecessary to a finding that "[i]mpatience, a lack of dignity, or discourtesy" constitutes sanctionable misconduct).

244. For example, in contrast to opinions recognizing the legitimacy of judges' personality and of their diverse judicial philosophies, the New Jersey Supreme Court opinions have emphasized the need " to subordinate one's personal pulls and one's private views." " In re Mathesius, 910 A.2d 594, 614-15 (N.J. 2006) (quoting Dunlap v. Friedman's, Inc., 582 S.E.2d 841, 850 n.4 (W. Va. 2003) (Davis, J., dissenting) (citations and internal quotations omitted)). Likewise, that court has emphasized the importance of preserving "the independence of the judiciary" as an institution (as distinct from the independence of individual judges) by disciplining judges whose conduct undermines public confidence in, and respect for, the judiciary. Id. at 608 (quoting In re Seaman, 627 A.2d 106, 121 (N.J. 1993)).

245. See, e.g., Hon. Charles D. Breitel, Ethical Problems in the Performance of the Judicial Function, in Conference on Judicial Ethics 64, 64-65 (U. Chi. Conference Series Oct. 22, 1964) (concluding that "the problems of judicial ethics in the 
Courts taking the rules literally have found certain judicial expressions to be sanctionable even when they do not implicate the fairness of the proceeding. For example, in In re Bennett, the Michigan Supreme Court suspended a probate judge, in part, for his "use of off-color language . . . in an entirely injudicious manner," 246 consisting of two uses each of the words "hell" and "ass." 247 The court expressed no concern that the offensive language somehow undermined the fairness of the proceedings. The court primarily regarded the judge's coarse language as inappropriate in judicial proceedings because it tarnishes the image of the judge and the judiciary. ${ }^{248}$ Similarly, the Third Circuit's decision in Krasnov $v$. Dinan, which upheld a district court's judgment on a jurisdictional issue, noted in passing that the district judge had violated the courtesy rule when, evidently impatient with the plaintiff's lawyer's procedural objections, he told the lawyer: "You can dissent until you drop dead. I'm sick and tired of hearing it."249 The appellate court found that nothing in the lawyer's advocacy in this case justified the trial judge's "injudicious remarks."250

actual performance of the judicial function are, with rare exceptions, aspects of one's personal philosophy and one's general legal philosophy" and observing that "the most important decision that the judge makes for himself is whether he will play an affirmative or quiescent role in the performance of his function").

246. 267 N.W.2d 914, 918 (Mich. 1978).

247. Id. The statements were: "[Y]ou were bombed on your ass," "[T] he defendant had a bad case of death resulting from numerous shotgun bullets up his ass," "I don't know what in hell they'll do with you," and "[T] here's about as much chance as a snowball in hell of us ever getting any money out of you." Id. The court observed that the judge's language "can only have been expected to offend, berate or intimidate the persons to whom it was addressed," id., and that, together with abusive off-the-bench statements, it "demonstrates a gross lack of judicial temperament," "is clearly prejudicial to the administration of justice," and "necessarily demeaned the office he holds." Id. at 919-20.

248. The court recognized that a judge may speak more colorfully "in the privacy of his or her office or among close acquaintances," id. at 918 , but mandated a more austere style on the bench, presumably to project an appearance that is contrary to the judge's real-life, off-the-bench self.

249. 465 F.2d 1298, 1303 n.2 (3d Cir. 1972). The court, however, rejected the plaintiff's claim that the judge's conduct was so hostile as to amount to a denial of due process. Id.

250. Id. The court acknowledged that " $[\mathrm{t}]$ rial tactics of energetic counsel may, at times, make it extremely difficult for a court to maintain a calm and dispassionate demeanor," but did not find that to be so here. Id. Its objection was not that the district judge failed to entertain the lawyer's arguments and, thus, deprived his client of a fair process. On the contrary, the appellate court might have considered it to be good courtroom management if, delivering the same message, the trial judge had said, "You are making the same points repeatedly; I have already ruled; you are free to raise your procedural objections on appeal, but you are 


\section{Enforcing the Courtesy Rules}

When courtesy rules are read literally by the courts, their reach might nevertheless be narrowed in practice by judicial conduct commissions, which have discretion whether to bring charges, and by courts, which have discretion whether to impose punishment. Certainly, the code drafters and some courts expect such discretion generally to be employed in judicial regulation. Recognizing that some of the rules, as written, cannot realistically serve as inviolable disciplinary standards, the judicial codes' drafters have relied on the enforcement authorities' discretion to temper the rules' excesses. Although the 1990 Code's preamble states that its provisions are "intended to govern conduct of judges and be binding on them," 251 it also acknowledges that "[i]t is not intended . . . that every transgression will result in disciplinary action."252 Likewise, some courts that take the courtesy rules literally acknowledge a policy of imposing discipline only in serious cases, such as those involving moral turpitude or a pattern of abuse. ${ }^{253}$

The state courts' reliance on state judicial commissions to exercise discretion to temper the overbreadth of the courtesy rules puts tremendous power in the commissions' hands. This is, at least implicitly, a powerful rejection of the idea of judicial independence in all of the senses in which Judge Tatel understood it-including the personal independence of judges to employ different philosophies and styles in managing their courtrooms; the independence of judges from the influence of their colleagues; and the independence of judges from non-judicial bodies. Indeed, the concerns expressed by Judge Tatel regarding encroachments on federal judges' independence are magnified in the state system.

The problem may be illustrated by In re Going, ${ }^{254}$ in which a family court judge explained to a pro se petitioner seeking visita-

using valuable district-court time for no good end by repeating them here." But from the appellate court's perspective, the trial judge's actual mode of expression, which made the point in a somewhat more informal, colorful and emphatic manner, had no place in the courtroom.

251. Model Code of Judicial Conduct preamble I 5 (1990).

252. Id. The Preamble continues: "Whether disciplinary action is appropriate, and the degree of discipline to be imposed, should be determined through a reasonable and reasoned application of the text and should depend on such factors as the seriousness of the transgression, whether there is a pattern of improper activity and the effect of the improper activity on others or on the judicial system." Id.

253. See, e.g., In re Mathesius, 910 A.2d 594, 613-14 (N.J. 2006).

254. In re Going, N.Y. State Comm'n on Judicial Conduct, 1997 WL 433228 (July 18, 1997). 
tion rights that he was requiring the petitioner to submit to a psychological evaluation "because it appears to me ... that you are more than a little nuts."255 The New York state judicial commission instituted proceedings against the judge and ultimately entered into an agreement that the judge would be publicly admonished based on an agreed-upon recitation of the relevant facts. The commission justified this on the ground that the judge's "disparagement of a litigant from the bench" was a breach "of judicial temperament" that impaired "the public's image of the dignity and impartiality of courts." "256

Significantly, the judiciary had no hand in the proceedings against Going and never reviewed them to determine whether the commission's theory of misconduct accorded with its own understanding of how the courtesy rules should be applied. ${ }^{257}$ The opinion justifying the sanction in Going, reciting a set of bare-bone stipulated facts, essentially lifted the family court judge's statements out of context, making it unclear to readers why (if at all) the remarks were sanctionable. Presumably, the commission's theory was that the word "nuts" is so gratuitously disparaging that it was highly improper for the judge to use it to describe the petitioner's affect or conduct. The commission's underlying theory of good judging is highly contestable, however. Family courts, a species of problemsolving courts, scarcely resemble the federal appellate courts with which the drafters of the original courtesy rules were most famil-

255. Id. The state commission recently relied on Going as authority in In re Pines, in which a family court judge was sanctioned for purportedly uncivil statements off the bench and in two court proceedings. In re Pines, N.Y. State Comm'n on Judicial Conduct, 2008 WL 4415139 (June, 17 2008). In one proceeding, the judge referred to a prisoner's request for joint custody as "patently ridiculous" and an "absolute waste of ... time," and referred to the prisoner's testimony as "inane" and as the most "ridiculous testimony [he had heard] in twelve years on the bench." Id. at *2. In the other, the judge told incarcerated parents seeking custody of their three children, "As far as I'm concerned, you're not in a position to take care of pets, much less children." Id. at *3.

256. Going, 1997 WL 433228.

257. Thus, this was not an instance as in McBryde of a proceeding instigated and overseen by judges. Disciplinary proceedings in Going were instigated by, and punishment was negotiated by, lawyer-staff members who serve full-time in a prosecutorial role. These staff members answered, in turn, not to a court or group of judges directly, but to an appointed commission. Although the disciplinary agency is nominally under the judicial branch, rather than the other government branches, it is hard to see how that makes much practical difference from the perspective of preserving individual judges' independence from third parties. See generally Sankar, supra note 214, at 1256-69 (distinguishing federal judicial commissions, which exercise collegial controls, with the California Commission on Judicial Performance, which exercises bureaucratic controls). 
iar. ${ }^{258}$ Based on his observations, the family court judge in Going might have considered it to be in the best interest of the petitioner and his child for the petitioner to obtain a psychological evaluation and, ultimately, appropriate psychological counseling or treatment. ${ }^{259}$ What the commission regarded as disparaging may have been, in the judge's view and perhaps in fact, the more effective manner of communicating with this particular party. For a commission and its staff to employ the disciplinary mechanism to take sides in a legitimate debate over the judicial role encroaches on the independence not only of the particular judge who is sanctioned but also of other judges who refrain from experimentation to avoid similar results. ${ }^{260}$ Arguably, the debate should be resolved through informal, non-punitive processes ${ }^{261}$ or through the reappointment or reelection process. Although a reviewing court might have concluded that the family court judge's approach in Going was legitimate-or, at worst, mistaken-as a practical matter the judge probably did not have an opportunity to offer this defense to the court. ${ }^{262}$

258. Of course, even in appellate courts, incivility is scarcely unknown, although easier to cloak from public view. For a discussion of incivility in the interpersonal relationships and dissenting opinions of U.S. Supreme Court Justices, see Edward McGlynn Gaffney, Jr., The Importance of Dissent and the Imperative of Judicial Civility, 28 VAL. U. L. Rev. 583, 626-44 (1994).

259. Family court judges have a high volume of cases in many of which they communicate directly with unrepresented parties. Judges legitimately perceive that their responsibility is not simply to rule on applications, but to influence parties proactively to do what is best for children and families, which often involves helping or prompting them to gain access to counseling and social services. Judges draw inferences about parties' needs based on direct interaction with them in the courtroom.

260. Besides chilling innovative judicial styles, the risk of discipline for judicial incivility may bias judges in favor of institutional parties, and especially those with political clout. For example, prosecutors and other government lawyers who appear in court regularly can keep track of judges' on-the-bench conduct and complain of those who issue unfavorable rulings that, in themselves, would not subject a judge to sanction. See, e.g., Oberholzer v. Comm'n on Judicial Performance, 975 P.2d 663, 683 (Cal. 1999) (dismissing disciplinary charge, originating with a complaint presumably filed by the prosecutor, that the trial judge acted uncivilly in dismissing a criminal charge); In re Duckman, 699 N.E.2d 872, 888 (N.Y. 1998) (removing judge whose investigation was prompted by his release of a misdemeanor defendant who subsequently committed homicide, and facilitated by two prosecutors' offices which provided transcripts documenting alleged abuses).

261. See, e.g., Peter A. Joy, A Professionalism Creed for Judges: Leading by Example, 52 S.C. L. REv. 667, 690-92 (2001) (advocating performance evaluations to promote judicial professionalism).

262. New York judges (and, perhaps, most judges) are notoriously underpaid, while New York legal fees are notoriously high; for a judge who subsists on his 
Although judicial conduct commissions might ordinarily proceed in only the most compelling cases, there is no reason to take that for granted. Judicial commissions have various incentives to proceed selectively against judges for borderline conduct, as in the Going case, while óverlooking more abusive conduct. Doing so establishes the commission's view of where the lines are drawn and deters judges from crossing it, while suggesting to the public that the commission is vigilant and not overly protective of the judiciary. Further, the civility rules can be invoked against judges who are controversial or disliked for reasons unrelated to sanctionable misconduct. Whether state commissions in fact target judges under the civility rules for unrelated reasons cannot be determined. ${ }^{263}$

It is difficult to reconcile a complex concept of judicial independence with state courts' delegation of broad discretion to judicial commissions to selectively prosecute cases of discourtesy. State courts that eschew conservative readings of the courtesy rules and place their faith in commissions comprised of lawyers and laymen, not exclusively judges, presumably regard neither the independence of individual judges nor that of judges collectively as paramount. The independence of the judicial branch, including administrators, law clerks, bailiffs, deputies, and judicial commissions, is paramount. In this view, judicial commissions are not a threat to judicial independence, even though judges may have little

salary, an effective defense would be prohibitively expensive. Thus, judicial commissions have not only enormous discretion, but also enormous leverage to enforce their own judicial philosophies through selective employment of the courtesy rules. An additional disincentive to seeking judicial review is that, at least in New York, the reviewing court is highly deferential to the judicial conduct commission. From 1978 to August 14, 2007, the Court of Appeals had dismissed the charges in only one of the eighty-five cases in which it reviewed determinations of the state Commission on Judicial Conduct (although the Court of Appeals did reduce the sanction in a number of cases). News Release, New York State Commission on Judicial Conduct (Aug. 14, 2007), http://www.scjc.state.ny.us/Press\%20Releases/ july_to_sept_2007.htm.

263. The judicial disciplinary process is not particularly transparent. The cases in which judicial commissions decline to proceed are not public. Judicial commissions do not publish, and probably do not develop, principles or guidelines to govern their exercise of discretion in bringing incivility charges. Further, published decisions are only the tip of the iceberg, since disciplinary prosecutions may end in private sanctions or none at all. For example, the judicial commission in California issues "advisory letters" when it believes that judicial misconduct does not warrant a public sanction. A 1999 California Supreme Court opinion noted that in the previous nine years, the state judicial commission had issued an average of thirty-seven advisory letters a year, of which the largest category involved the rule requiring judges to be "patient, dignified and courteous." Oberholzer, 975 P.2d at $671-72$ n.8. 
influence over them, because the commissions are part of a judicial bureaucracy into which judges, individually and collectively, are subsumed. The selective enforcement of courtesy rules leads judges to accept their role in the collective enterprise alongside the full panoply of judicial personnel and to privilege the independence of the judiciary as an occasionally threatened branch of government over that of judges themselves.

\section{Courtesy and the Veneer of Neutrality}

In a characteristically prophetic moment in 1897 , Oliver Wendell Holmes, Jr. wrote, "[T] he logical method and form flatter the longing for certainty and for repose which is in every human mind. But certainty generally is an illusion, and repose is not the destiny of man."264 Maybe not. However, at times of unrest particularly, popular opinion seeks that certainty. It gravitates not only toward the logical method but also toward a particular image of the judicial process and the judge that satisfies that same longing. This is particularly so when the courts have been asked to serve as final arbiters of controversial and socially divisive questions.

At his confirmation hearings, John Roberts emphasized qualities of "modesty" and "humility" in a judge and famously suggested that judges "call balls and strikes"; they do not hit or pitch. ${ }^{265} \mathrm{He}$ further elaborated on the view of judges as umpires, interpreting but not making law, in an interview with Jeffrey Rosen published in the Atlantic Monthly. ${ }^{266}$ Roberts suggested that there should be fewer colorful personalities on the bench and more considered reasoning; fewer dissents and more unanimous opinions. ${ }^{267}$ The problem, as Roberts described it, was "the personalization of judicial politics." 268 Roberts explained, "What you're trying to establishwearing black robes and, in earlier times, wigs-[is] that it's not the person; it's the law."269

Most judges, academics, and first-year law students, however, would agree that this statement about the judicial process is simply not accurate. There is too much ambiguity in the law and too much room for manipulation. Every judicial decision, to some degree or another, reflects the personal views, ideology, and intuition

264. Holmes, supra note 101 , at 466.

265. Confirmation Hearings, supra note 5, at 56.

266. Jeffrey Rosen, Roberts's Rules, Atlantic Monthly, Jan./Feb. 2007, at 104. 267. Id.

268. Id. at 106 .

269. Id. at 112. 
of the judge. ${ }^{270}$ There may nonetheless be some good in obscuring that reality, especially since there is no consensus about the appropriate tools to use when the law fails to dictate an outcome.271 Denying that judges bring personal views and biases to their decisions may restore faith in the judiciary; but at the same time, it involves a cost to the quality of judging and the transparency of the process. ${ }^{272}$

The black robes and wigs are symbols of a particular kind of judging. For Chief Justice Roberts, they are metonyms for objective and impersonal justice. ${ }^{273}$ In order to be free from discretion, such judging requires the suppression of individual personality and ideology. The history of attitudes and rules concerning judicial temperament shows that the impulse to depersonalize the judiciary generally masks an effort to justify a kind of judicial activism, which is not necessarily informed by the role that judges actually play.

Rules concerning judicial courtesy and other such symbolic remnants of an earlier time perpetuate the myth of discretion-free judging, but avoid confronting the fact that that myth is so terribly outdated. In other words, the trappings of an older time appear as a comforting and uncontroversial consistency when they are, in fact, part of a broader effort to impose a particular judicial style and resurrect a particular jurisprudential view. ${ }^{274}$

One of the dangers of this attempt to dehumanize the judiciary is that it threatens to lend it an artificial legitimacy, a false sense of security in its own mission. By making it appear as if judges are simply applying the law, the impersonal image of the judge lends a superficial justification for an active and significant role for the judiciary in the democratic process. In the 1920s, the Canons of Judi-

270. Recently, Chris Guthrie, Jeffrey Rachlinski, and Andrew Wistrich relied on empirical studies to demonstrate how judges think. They argue that judging involves a complex interaction between intuition and deliberation. See Chris Guthrie et al., Blinking on the Bench: How Judges Decide Cases, 93 CoRNELI L. REV. 1, 2-13 (2007).

271. Ferejohn \& Kramer, supra note 7, at 970-71.

272. Cf. Resnik, supra note 1 , at 428-31 (describing the lack of impartiality of trial judges). There has been interesting recent empirical work on the nature of judicial decision making, which concludes that judges are subject to the same cognitive illusions as most anyone else. See Chris Guthrie et al., Inside the Judicial Mind, 86 CORNELL L. REv. 777 (2001).

273. Rosen, supra note 266, at 112.

274. See Michael Bentley, Island Stories: The British Historical Tradition and Its Afterlife, Times Lrterary Supplement, Oct. 13, 2006, at 5 (noting the persistence of the myth of objectivity in certain disciplines including British history and the inability of those disciplines to come to terms with the implications of indeterminacy without abandoning the entire professional endeavor). 
cial Conduct, with their promotion of proper judicial demeanor, provided cover for the Lochner Court's activism. ${ }^{275}$ In fact, this was precisely what the authors had in mind. ${ }^{276}$ The Canons were designed to project an image of the judiciary that would relieve the public of the growing suspicion that courts were imposing their own ideology and taking sides in a political battle. It is now fairly well recognized that courts were, in fact, interpreting statutes and state and federal constitutions in light of particular policy preferences. 277 Judges justified an active stance toward legislative pronouncements by relying on the special and objective nature of the law, rather than elaborating or even acknowledging their own ideological views. ${ }^{278}$ But recognizing that law involves the politics and preferences of judges would lead to a healthy dose of humility. ${ }^{279}$ Chief Justice Roberts's preference for eliminating all signs of ego and personality runs a risk of masking judicial activism in the guise of neutrality.

While promoting a superficial faith in the judiciary, formalism and the image of the detached judge also run the risk of distracting judges and scholars from uncovering new sources of legitimacy for the judiciary that have more to do with quality than the appearance of neutrality. In other words, rather than serving to enhance the administration of justice, independence as it has been conceived can undermine judicial quality. ${ }^{280}$ The fallacy is that judicial decisions can be determined without resort to personal ideology and intuition, and this forces judges to hide from themselves and others the true cast of their reasoning. ${ }^{281}$

275. See supra Part II.B; see also United States v. Lochner, 198 U.S. 45 (1905); Howard Gillman, The Constitution Besieged: The Rise and Demise of Lochner Era Police Powers Jurisprudence (1993) (explaining that Lochner grew into a symbol of judges usurping legislative authority by drawing on their own policy preferences to invalidate state and federal legislation).

276. See supra Part II.B.

277. See HoRWTz, supra note 2, at 53; KALMAN, supra note 98, at 50-51.

278. See supra Part II.

279. See Richard A. Posner, The Problematics of Moral and Legal Theory 242, 255-65 (1999); Cass Sunstein, Legal Rrasoning and Political Conflict 24-25 (1996). See generally Cass Sunstein, The Supreme Court, 1995 Term-Foreword: Leaving Things Undecided, 110 HARV. L. REv. 4 (1996) (arguing for a democracyforcing form of minimalism in judging controversial, unsettled issues).

280. See Ferejohn \& Kramer, supra note 7, at 965-76 (arguing that independence ought not to be an end in itself but rather a means to achieve judicial quality).

281. Chemerinsky, supra note 3, at 1078-79 (arguing that the myth of discretion-free judging distorts the true meaning of judicial decisions because it encourages judges to obscure the real process of reasoning from themselves and from 
As Judge Richard Posner explains, formalism promotes a kind of judicial laziness. ${ }^{282}$ It allows judges to ignore necessary facts and disguise their lack of knowledge at the same time. It encourages the judiciary to develop without sensitivity to its limitations and leaves the public with opinions that obscure the actual basis of the courts' decisions. In contrast, basing decisions explicitly on a complex and interdisciplinary understanding of the underlying facts at issue in the case might lend the judiciary another source of legitimacy based on what Posner refers to as the "good kind of professionalism," or the mastery of specialized knowledge. 283 Posner opposes this true claim to professional status to a bad kind of professionalism, based almost entirely on "mystique"-the tricks that a profession develops to give the impression of its own importance in the absence of a true claim to knowledge. ${ }^{284}$ Courtesy rules, like the other trappings of formalism, become a part of the professional mystique, which ironically deters the judiciary from developing a mastery of knowledge, which might give it claim to the good sort of professionalism. The true mastery of knowledge, in turn, might provide a different sort of legitimacy based more on quality than on the appearance of neutrality.

\section{E. Alternative Sources of Legitimacy}

Professor Michael Dorf proposes a new potential source of legitimacy for the judiciary which requires abandoning the older notion of judicial neutrality. He describes this source as "experimentalist judging," an active and participatory style in which judges collaborate with the litigants, institutions, agencies, and others involved in a case to come up with the most socially useful resolution. ${ }^{285}$ Judicial neutrality, he explains, no longer requires a judgment free from political, ideological, or personal considera-

others); Richard A. Posner, The Role of the Judge in the Twenty-First Century, 86 B.U. L. REV. 1049, 1051-58 (2006).

282. POSNER, supra note 279 , at $240-42,262-64$.

283. See id. at 187.

284. Id. at 187-92. Posner relies heavily on the sociology of the professions. A long line of sociologists have contributed to an understanding of a profession not as a group with a mastery of particular knowledge but rather a group that has managed to manufacture the perception that it has such mastery. See, e.g., ANDREw Abbott, The System of Professions: An Essay on the Division of Expert Labor (1988); Eliot Friedson, Professionalism Reborn: Theory, Prophesy, and Policy (1994); Magali Sarfatti larson, The Rise of Professionalism: A Sociological ANALYSIS (1979).

285. See Michael C. Dorf, Legal Indeterminacy and Institutional Design, 78 N.Y.U. L. REV. 875, 935-38 (2003). 
tions. It simply requires a judge who has no stake in the outcome. ${ }^{286}$ The ideal judge in this picture would be active and involved personally in his cases. In the context of community courts, Professor Dorf explains, a more active and colorful judicial style would do more to lend legitimacy to the judicial process. ${ }^{287}$ In order to deal effectively with parties, institutions, and government officials, judges may need to become emotionally entangled. In juvenile court, they may need to scold; in family court, they may need to exhort; in community court, they may need to yell to get their point across.

In such courts, goals of adjudication are determined by democratically elected legislatures, but judges ascertain the just result in an ongoing exchange with the local community. ${ }^{288}$ Many courts already operate on the local level, and judges in those courts especially ought to be able to use their personalities to engage actively with the litigants and others to lend a different sort of legitimacy to the branch.

In addition, promoting the image of a detached judge, who applies but does not make the law, comes at a cost to diversity in judicial styles. It imposes one brand of judging on the entire branch, both state and federal. To the authors of the 1972 Code of Judicial Conduct, the courtesy rules stood for a kind of bureaucratic detachment and enforced regularity. By affirming the rules of judicial temperament, the authors attempted to create judges in one mold. By allowing judges to police one another based on this code and turning the judiciary into a kind of bureaucracy, the state judiciaries discouraged renegade judges with different styles and different ideological and jurisprudential views.

As Benjamin N. Cardozo argued, something greater than the sum of its parts emerges from the "attrition of diverse minds." 289 We do not want one sort of judge, in part because there is no way of determining if any one style of judging is better than any other. ${ }^{290}$ Furthermore, judges in contemporary America perform such different functions that even if one judicial style were superior to another in one context, the same would not hold true in another. Federal judges perform a different function from state court judges, appellate judges do different work from trial and magistrate judges.

286. See id. at $953-54$.

287. See id. at 947-54.

288. See generally Michael C. Dorf \& Charles F. Sabel, Drug Treatment Courts and Emengent Experimentalist Government, 53 VAND. L. REv. 831 (2000).

289. CARDOZO, supra note 103 , at 177 .

290. See PoSNER, supra note 279 , at 257-65. 
Judges in criminal court have different concerns from those in family, community, or drug courts. Allowing judges room to develop their own styles in relation to the business before them will help us to explore new forms of legitimacy for the judicial branch. It will allow us to analyze how different styles are suited to different judicial roles. It may also help us avoid a bland kind of mediocrity and allow us, by chance, to stumble on something greater.

\section{CONCLUSION}

It is harmful to the quality of judging to pretend that judging is entirely rational, freed from emotion and passion. It is destructive to ask judges to ignore their emotional responses, as they were asked to do in the late nineteenth century. As Justice William J. Brennan argued, judging cannot "properly be characterized as simply the application of pure reason to legal problems, nor, at the other extreme, as the application of the personal will or passion of the judge."291 Paying tribute to Justice Cardozo, Brennan explained that "Cardozo drew our attention to a complex interplay of forces-rational and emotional, conscious and unconscious-by which no judge could remain unaffected."292 Emotion and passion are not qualities that we are forced to tolerate solely because they are inextricable from the decision-making process. Thus, "[s] ensitivity to one's intuitive and passionate responses, and awareness of the range of human experience, is therefore not only an inevitable but a desirable part of the judicial process, an aspect more to be nurtured than feared."293 Richard Posner has echoed this assertion: "Emotion is a form of thought, though compressed and inarticulate, because it is triggered by, and more often than not produces rational responses to, information."294 This leads us finally back to the assumption that rather than ask judges to turn themselves into "oracles of pure reason," 295 we ought to promote a diverse judiciary with a variety of intuitions, emotional responses as

291. Brennan, supra note 157, at 3; see also Guthrie et al., supra note 270 (arguing that intuition, emotion, and reason all play a role in judging).

292. Brennan, supra note 157 , at 3 .

293. Id. at 10. Brennan defines passion as "the range of emotional and intuitive responses to a given set of facts or arguments, responses which often speed into our consciousness far ahead of the lumbering syllogisms of reason." Id. at 9.

294. Posner, supra note 281, at 1063.

295. Brennan, supra note 157 , at 5 . This conclusion is also in keeping with an observation made by Professors Ferejohn and Kramer that independence is not a goal in itself but rather a means to an important end, a well-functioning judiciary. Ferejohn \& Kramer, supra note 7, at 963-64. 
well as deliberative tools, and out of that, we can hope for something better than the sum of its parts.

Given the diversity of theories about how judges should decide cases, the system ought to value a form of independence that allows judges to develop adjudicatory styles in accord with their own personal and professional views. Because they contribute to a notion of a detached and purely rational judge, the judicial courtesy rules run the risk of imposing a particular judicial style at odds with this goal. Furthermore, there are times when a judge is asked to answer questions that involve irreducible uncertainty, when no theories, philosophies, or other disciplines provide an adequate solution. In many courts, that kind of uncertainty is more the rule than the exception. In those cases particularly, a judge ought to be free to draw on his own intuitions and even passions without fear of negative consequences. To encourage this sort of judging, judicial conduct commissions ought to be cautious and sparing in their use of the courtesy rules. 
